MALDONADO, Francisco. "Amenazas y coacciones en el Derecho Penal Chileno".

Polít. crim. Vol. 13, № 25 (Julio 2018) Art. 1, pp. 1-41.

[http://www.politicacriminal.cl/Vol_13/n_25/Vol13N25A1.pdf]

\title{
Amenazas y coacciones en el Derecho penal chileno.
}

\section{Threats and coercion in chilean criminal law.}

\author{
Francisco Maldonado Fuentes \\ Director del Centro de Estudios de Derecho Penal \\ Profesor de Derecho Penal de la Universidad de Talca \\ Franciscomaldonado.2006@gmail.com
}

\section{Resumen}

El artículo busca dar cuenta de los problemas que ofrece la sistemática de las amenazas y coacciones en el derecho chileno (si bien constituyen dificultades comunes en buena parte de los modelos comparados de referencia forzosa en nuestro medio) sus implicancias dogmáticas y en materia de interpretación del texto positivo del Código Penal. A partir de ello analiza las dos modalidades de aproximación ofrecidas por la doctrina local, centradas, a su vez, en dos formas alternativas de conceptualización de las amenazas (como atentado a la seguridad individual o como delito contra la libertad de autodeterminación), concluyendo que, más allá de sus razones, ofrecen conclusiones insuficientes para explicar adecuadamente las decisiones adoptadas por nuestro legislador. Finalmente ofrece una propuesta alternativa -sostenida en Chile por Etcheberry, pero sin un desarrollo más acabado- y las razones que la respaldan, centrada en dos ideas centrales: la amenaza condicional y la coacción constituyen formas de constricción o coerción mientras que la amenaza simple incide sobre la seguridad individual; amenaza e intimidación se diferencian por razones referidas a inmediatez o unidad de contexto, proponiendo por ello una diferencia esencial en los respectivos supuestos incriminados.

Palabras clave: Delitos contra la libertad; coacciones, amenazas.

The article describes the problems offered by the system of threats and coercion in chilean law (although they are common difficulties in many of the comparative systems of forced reference for our country), their dogmatic consequences and interpretations of the Criminal Code. Taking into consideration that basis, the article analyzes two different approaches offered by local doctrine centered, in turn, on two alternative forms of conceptualizing threats (as an attempt to individual safety or as a crime against the freedom of self-determination). The paper proposes that, beyond their reasons, these approaches arrive to insufficient conclusions to explain the decisions taken by our legislator. Finally, focusing on two central ideas, offers an alternative proposal -supported in Chile by Etcheberry, but without further development- and the reasons that support it: the conditional threats and coercions constitute ways of constriction or restraint, meanwhile simple threats affects individual safety. Indeed, threats and intimidation differ from each other because of immediacy or context unity reasons, identifying, thus, a key difference among the description of each crime.

Key words: Crime against the freedom of self-determination, coercion, threats. 
MALDONADO, Francisco. “Amenazas y coacciones en el Derecho Penal Chileno”.

\section{Los problemas que ofrece la regulación de las amenazas y coacciones en el derecho penal chileno. A modo de introducción}

La presente contribución pretende aportar en la discusión -escasa, por cierto- referida a la interpretación que cabe dar a los supuestos incriminados bajo el título de las amenazas y coacciones en el Derecho penal chileno. Dicho objetivo se justifica a nuestro entender por el solo hecho de que la doctrina nacional ofrece una diversidad de opiniones sobre la forma como deben ser comprendidos buena parte de los elementos que definen los correspondientes tipos penales, sin que exista claridad al respecto o, cuando menos, un estado de síntesis nítido ${ }^{1}$. Hay que tener en cuenta que dicha indeterminación incide en particular sobre la comprensión que cabe dar a aquellos elementos que resultan esenciales o definitorios de las respectivas estructuras fundamentales de dichos delitos, como sucede con el medio comisivo en las coacciones -en especial, qué se entiende o debe entenderse por "violencia"- o con el rol o funcionalidad que cabe asignar a la "condición" que acompaña a "las amenazas".

Este estado de cosas no es en cualquier caso una característica propia de nuestro sistema jurídico. Lo cierto es que la naturaleza propia de las amenazas, su relación con los tipos de "coerción" en particular -cualquiera sea su contenido- y la interpretación que cabe dar a cada una de las figuras incriminadas bajo dichos rótulos, es y ha sido objeto de viva controversia histórica en los diversos sistemas jurídicos ${ }^{2}$. Es también posible constatar que las diversas regulaciones parecieran favorecer este estado de incertidumbre, sea por el hecho de que los diversos esquemas de tratamiento positivo no ofrecen una estructura sistemática que permita en forma nítida identificar el contenido que opera como referente de la protección penal que se pretende disponer -todos los sistemas presentan reglas que resultan disfuncionales respecto de la asunción de alguna de las posturas en juego ${ }^{3}$ - como también por el hecho de que tanto las amenazas como las coacciones proponen sentidos o significados que son y han sido valorados en forma dispar por el legislador penal en momentos y lugares diversos a través de la historia ${ }^{4}$.

En relación a esto último se debe tener en cuenta que la conducta consistente en amenazar a otro -esto es, la advertencia de males sujeta exclusivamente a una decisión del agente que las

\footnotetext{
${ }^{1}$ Al respecto véase BASCUÑÁN RODRÍGUEZ, Antonio, "Delitos contra intereses personalísimos", en Revista de Derecho de la Universidad Adolfo Ibañez (2005), pp. 531 a 556, p. 532, nota n³.

${ }^{2}$ Al respecto, por todos, GUZMÁN DÁLBORA, José Luis, El delito de amenazas, Santiago (Chile): Editorial Jurídica Conosur, 1999, pp. 18 y 87 y ss.; Con detalle en torno al caso español BASCUÑ̂́N RODRÍGUEZ, Antonio, "La regulación española de la coerción en el marco de la codificación penal europea", en Anuario de Derecho Penal y Ciencias Penales, Tomo 47, Fasc. 3 (1994), pp. 191 a 306, pp. 195 y 196; y en BASCUÑÁN, Antonio, "La protección penal de la libertad personal", material de estudio para los estudiantes de la Facultad de Derecho de la Universidad Adolfo Ibañez, 2001 - 2003, material inédito facilitado por el autor, p. 14.

${ }^{3}$ Por todos, GUZMÁN DÁLBORA, El delito, cit. nota nº2, p. 20.

${ }^{4}$ Al respecto BASCUÑÁN RODRÍGUEZ, "La regulación”, cit. nota n², p. 197; Asimismo BASCUÑ̃́N, Antonio, "El Robo como coacción", Revista de Estudios de la Justicia, n¹ (2002), p. 100 y en particular en nota 144. Por su parte, GUZMÁN DÁLBORA, El delito, cit. nota nº2, p. 19, pone de relieve que el origen relativamente contemporáneo de los delitos contra la libertad y la seguridad incide en forma determinante en dicha dispersión e indeterminación. Concretamente sobre la confusión imperante en las discusiones en el siglo XIX y XX sobre la idea de libertad como objeto de protección penal véase GUZMÁN DÁLBORA, El delito, cit. nota $\mathrm{n}^{\circ} 2$, p. 20, y con respecto a la noción de seguridad individual, pp. 156 y 157.
} 
Polít. crim. Vol. 13, № 25 (Julio 2018) Art. 1, pp. 1-41.

[http://www.politicacriminal.cl/Vol_13/n_25/Vol13N25A1.pdf]

emite $^{5}$ - puede ser valorada como expresión de una agresión futura sobre la integridad de los intereses de otro o, alternativamente, puede evidenciar la pretensión de interferir en la libertad de decisión de dicho destinatario ${ }^{6}$. Bajo la primera conceptualización muestra relevancia como atentado a la seguridad colectiva o individual, mientras que en la segunda opera más bien como forma o medio coercitivo, vinculándose por ello a la libertad de autodeterminación.

Por su parte, hay que considerar, como dato adicional, que la relevancia atribuida a la coerción individual en las diversas legislaciones penales ha sido disímil, ofreciendo un contenido variable a través de la historia. Su reconocimiento ha estado directamente condicionado por el diverso énfasis atribuido al respeto y necesidades de protección de la propia autonomía individual en cada momento y lugar ${ }^{7}$. De esta forma es posible identificar épocas y contextos históricos donde la necesidad de tutela penal se limita a expresiones precisas y determinadas de la libertad (las más relevantes en términos políticos), de manera que se tiende a descartar la necesidad de una figura básica o general de coerción ${ }^{8}$. Así sucede en términos paradigmáticos en el modelo instaurado en la codificación francesa y aquellos que le siguen, donde se proponen expresiones específicas de protección (como sucede de forma paradigmática con la libertad de desplazamiento) ${ }^{9}$. En otros casos, la relevancia asignada a la coerción se limita a la eventualidad de que sea utilizada como medio para la afectación de intereses ajenos a su contenido propio -paradigmático en la extorsión-, siendo estos los que aportan el mérito que lleva a disponer de la represión penal ${ }^{10}$. Finalmente, es posible identificar modelos a través de los cuales se le reconoce y asigna un sentido de valor autónomo y de carácter general a la libertad individual, que se expresa -inequívocamenteen la consagración de un delito de coerción de carácter basal, genérico o supletorio. En dicho contexto resultan irrelevantes los caracteres del modo comisivo, sea que se exprese a través de la fuerza o la violencia física o mediante alguna forma de coacción moral o inmaterial ${ }^{11}$.

\footnotetext{
${ }^{5}$ En este sentido BASCUÑÁN RODRÍGUEZ, “La regulación”, cit. nota n², p. 286.

${ }^{6}$ PAREDES CASTAÑÓN, José Manuel, “Libertad, seguridad y delitos de amenazas”, Estudios Penales y Criminológicos, Vol. XXIX (2009), p. 363.

${ }^{7}$ Como indica BASCUÑÁN RODRÍGUEZ, “La regulación”, cit. nota n², p. 197, "El derecho penal europeo continental conoce dos modelos básicos de regulación de la coerción diametralmente opuestos, el francés y el alemán. Salvo la codificación española, el resto de las regulaciones europeas de la coerción puede de una u otra forma ser reconducido a uno de estos dos modelos. Así, por ejemplo, la regulación belga sigue el modelo francés, y las regulaciones italiana y austriaca siguen el modelo alemán".

${ }^{8}$ A nivel general, lo dicho constituye un signo evidente del tipo de conceptualización y de la estructura de tratamiento que se propone en las diversas regulaciones. Al respecto véase BASCUÑÁN RODRÍGUEZ, "La regulación", cit. nota $\mathrm{n}^{\mathrm{0}} 2$, p. 198

9 Sobre la génesis y evolución de este modelo véase BASCUÑÁN RODRÍGUEZ, "La regulación”, cit. nota n², pp. 204-210. Asimismo, GUZMÁN DÁLBORA, El delito, cit. nota n², pp. 69-70.

${ }^{10}$ Sobre ello, concretamente, BASCUÑÁN RODRÍGUEZ, "La regulación”, cit. nota n², p. 209. Asimismo, MIRA BENAVENT, Javier, "El concepto de violencia en el delito de coacciones", Cuadernos de Política Criminal, No22 (1984), p. 99.

${ }^{11}$ Lo relevante a este respecto es que ambas modalidades de conducta solo resultan equivalentes -en términos funcionales- si se las conceptualiza como formas de constricción o coerción. Al margen de ello se trata de formas de conducta que pueden recibir una valoración diferenciada si se las analiza desde otras perspectivas o referentes según pasamos a revisar en el texto.
} 
MALDONADO, Francisco. “Amenazas y coacciones en el Derecho Penal Chileno”.

Lo dicho se advierte en la tradición asociada al modelo que ofrece la regulación germana e italiana propia de la época de codificación ${ }^{12}$.

A este panorama debemos además agregar -en un sentido aún más problemático- que tanto la "violencia" como la "advertencia de males" reciben a través de la historia diversos significados o sentidos desde el punto de vista de las razones que apoyan su incriminación. Así, por ejemplo, "la violencia" 13 es valorada en cuanto infringe el monopolio del ejercicio de la fuerza por parte del Estado -adscrito tradicionalmente a la conceptualización tradicional del llamado crimen vis ${ }^{14}$; como forma de agresión corporal o expresión de maltrato físico en el campo de los atentados a la integridad personal ${ }^{15}$; o, finalmente, como modalidad o forma de constricción o coerción ${ }^{16}$. La "advertencia de males" ("amenaza") -de ejecución inminente o futura- comparte este último papel siendo además interpretada como un atentado a la seguridad individual de las personas. Por último, también se debe tener en cuenta que las propias nociones de seguridad o de libertad no ofrecen un sentido o significado unívoco como potenciales bienes jurídicos, existiendo diversas posturas en cuanto a la precisión de sus contenidos propios ${ }^{17}$.

${ }^{12}$ Con respecto a la regulación alemana véase GUZMÁN DÁLBORA, El delito, cit. nota n², p. 74-75, destacando un conjunto de regulaciones adicionales donde tiene influencia en pp. 77-86. Dichas referencias se complementan con un desarrollo histórico de la doctrina correspondiente en pp. 110-114. Sintéticamente, TORÍO LÓPEZ, Ángel, "La estructura típica del delito de coacción", Anuario de Derecho Penal y Ciencias Penales, Tomo XXX, Fasc. 1 (1977) p. 21; Asimismo, véase BASCUÑÁN RODRÍGUEZ, "La regulación", cit. nota n², pp. 218-243. Más sintético ETCHEBERRY, Alfredo, Derecho Penal, Santiago (Chile): Editorial Jurídica de Chile, $3^{\circ}$ edición revisada y actualizada, 1997, Tomo III, p. 197, quien radica los orígenes de esta conceptualización en Feuerbach y en el CP de Baviera. Con respecto a la regulación italiana véase GUZMÁN DÁLBORA, El delito, cit. nota n ${ }^{\circ}$, pp. 76-77, incluyendo las referencias doctrinales en pp. 115-118. Asimismo, BASCUÑÁN RODRÍGUEZ, “La regulación”, cit. nota n², pp. 256-267.

${ }^{13}$ Para una panorámica acerca de las discusiones suscitadas al respecto véase JAKOBS, Günther, "Coacciones por medio de violencia", traducción y estudio preliminar a cargo de PEÑARANDA, SUÁREZ y CANCIO, en: EL MISMO, "Estudios de Derecho Penal", Madrid: Edit. Civitas, 1997, pp. 439 a 459, pp. 441 y ss.

${ }_{14}$ Al respecto ETCHEBERRY, Derecho Penal, cit. nota $n^{\circ}$ 12, p. 196 y 197. Asimismo, BASCUÑ́n RODRÍGUEZ, "La regulación", cit. nota n², p. 199.

${ }^{15}$ Así se aprecia en el modelo del Código Penal francés de 1810. Al respecto BASCUÑÁN RODRÍGUEZ, "La regulación", cit. nota n², p. 209. Ver asimismo MIR PUIG, Santiago, "El delito de coacciones en el código penal", Anuario de Derecho Penal y Ciencias Penales, Tomo XXX, Fasc. 2 (1977), p. 275.

${ }^{16}$ Sobre las razones que llevan a conceptualizar la violencia como hipótesis de coerción, BASCUÑÁN RODRÍGUEZ, "La regulación", cit. nota n², pp. 199 y 202. Dichas explicaciones dan cuenta, asimismo, de cómo la coerción llega a adquirir mérito para una consideración autónoma en el modelo alemán, a partir de su recepción -resistida inicialmente, en su tiempo- en autores como Grolman y el posterior desarrollo de Tittmann. Al respecto véase BASCUÑÁN RODRÍGUEZ, "La regulación”, cit. nota n², p. 220. En un sentido similar GUZMÁN DÁLBORA, El delito, cit. nota nº, p. 42, quien enfatiza cómo dicho desarrollo -en torno a la coerción- ubica su evolución en un lugar lejano al devenir que experimenta el tratamiento de las amenazas. Estas parecieran más bien extraerse del tratamiento original ofrecido por el derecho romano donde se las identifica como formas de "injuria", más allá de reconocer el "parentesco" de ambas figuras. Al respecto, GUZMÁN DÁLBORA, El delito, cit. nota n², pp. 46 y ss.

${ }^{17}$ En relación a la libertad, el debate tradicional se concentró en la posibilidad de brindar protección a la libertad de decisión del individuo -entendida como capacidad general y propiedad humana- y la mayor especificidad y concreción que ofrece la capacidad de actuación o ejercicio del individuo, inclinándose las diversas posturas en favor de esto último. Al respecto véase GUZMÁN DÁLBORA, El delito, cit. nota n², pp. 118 y ss. Se debe mencionar además que las discusiones suscitadas en torno a la delimitación de la frontera que separa las amenazas condicionales y las coacciones llevó a identificar como bienes autónomos e independientes a la 
Polít. crim. Vol. 13, No 25 (Julio 2018) Art. 1, pp. 1-41.

[http://www.politicacriminal.cl/Vol_13/n_25/Vol13N25A1.pdf]

Como señalamos al comenzar estas líneas, cada una de estas definiciones se expresa en términos complejos en los diversos regímenes positivos, lo que a fin de cuentas produce sistemáticas que -por desgracia- se estructuran a partir de definiciones que no dan cuenta en términos inequívocos de la conceptualización que motiva sus respectivos fundamentos. En concreto, la totalidad de las reglas previstas no se corresponden en forma precisa con una determinada concepción sobre el sentido que cabe atribuir a la "amenaza" o a la "violencia" en forma autónoma o como formas de coerción, ofreciendo relaciones sistemáticas que muestran algún grado -mayor o menor- de indeterminación.

Conviene tener en cuenta, finalmente, que estas problemáticas no solo impactan sobre las reglas que tipifican las "amenazas" o "coerciones" (coacción) en cualquier sistema jurídico, sino que también extienden sus implicancias a todas aquellas figuras que recurren a dichas modalidades de conducta como forma de ataque para la lesión de aspectos o expresiones específicas de la libertad (ambulatoria o sexual, por ejemplo) o para la protección de intereses diversos (como la propiedad o el patrimonio) ${ }^{18}$, constituyendo una materia que por ello detenta incidencias en una amplia gama de conductas incriminadas en la legislación penal.

capacidad de adoptar decisiones y ejecutarlas (asumidas como expresiones físicas de la libertad) y la capacidad de motivarse al margen de interferencias indebidas, adscribiendo las primeras en torno a la coacción y la segunda a las amenazas condicionales, todo ello a partir de la clásica tripartición que en su tiempo ofreciera Binding. Al respecto BASCUÑÁN RODRÍGUEZ, "La regulación", cit. nota no2, pp. 193 y 194. Véase asimismo GUZMÁN DÁLBORA, El delito, cit. nota n², pp. 103 y ss. y JASO ROLDÁN, Tomás, "Capítulo XXX”, en: ONECA, Antón y RODRÍGUEZ MUÑOZ, J.A., Derecho Penal. Tomo II. Parte especial, Madrid: Gráfica Administrativa, 1949, p. 298. En lo referido al bien jurídico "seguridad", las alternativas van desde su conceptualización como referente de la seguridad general o colectiva; como acto preparatorio de riesgo para los respectivos bienes jurídicos que son objeto de la amenaza; como continente de la seguridad jurídica respecto a los derechos básicos reconocidos a cada individuo o, finalmente, como un referente asociado a la tranquilidad que debe gozar cada persona como facultad reconocida (donde el resultado relevante es la provocación de temor). Sobre ello JAREÑO LEAL, Ángeles, Las amenazas y el chantaje en el Código Penal de 1995, Valencia: Tirant lo Blanch, 1997, p. 17; LORENZO SALGADO, José Manuel, "El delito de amenazas. Consideraciones sobre el bien jurídico protegido", Estudios Penales y Criminológicos, nº12 (1987-1988), p. 254; LARRAURI, Elena, Libertad y amenazas, Barcelona: Edit. PPU, 1987, pp. 219 y ss.; GUZMÁN DÁLBORA, El delito, cit. nota $\mathrm{n}^{\circ 2}$, pp. 144 a 156; BASCUÑÁN RODRÍGUEZ, "La regulación", cit. nota n², p. 285. Hay que tener presente que las diversas formas y contenidos que ofrece la noción de seguridad como bien jurídico proviene de la consolidación de la idea de que su conceptualización como "tentativa anticipada" presenta serios problemas de justificación. De ahí que se haya pretendido identificar el sentido de la protección que brindan las amenazas simples (no condicionales) en un referente diverso. Al respecto. Vid. LARRAURI, Libertad, cit. nota $\mathrm{n}^{\circ} 17$, p. 29. Véase asimismo infra nota 86.

${ }^{18}$ Lo destaca como cuestión central GUZMÁN DÁLBORA, El delito, cit. nota n², p. 19 (en especial en nota 13). Se advierte concretamente en torno al tratamiento del delito de robo en BASCUÑÁN RODRÍGUEZ, "El Robo", cit. nota n4, pp. 57 y 58; MERA FIGUEROA, Jorge, Hurto y Robo, Santiago: Edit. Lexis Nexis, 1995, pp. 113, 117 y ss., 133 y ss.; OLIVER, Guillermo, "Consideraciones sobre la violencia y la intimidación en el Robo", en VVAA, La ciencia penal en la Universidad de Chile. Libro homenaje a los profesores del departamento de Ciencias Penales de la Facultad de Derecho de la Universidad de Chile, Santiago: Ediciones Universidad de Chile, 2013, pp. 465 y 467 y ss. En relación a la realización arbitraria del propio derecho, MAÑALICH, Juan Pablo, Autotutela del acreedor y protección penal del deudor. La realización arbitraria del propio derecho frente a los delitos contra la libertad, la propiedad y el patrimonio, Santiago: Ediciones Jurídicas de Santiago, 2009, pp. 53 y ss. y 99 y ss. y SOTO PIÑEIRO, Miguel, "Nota y comentario de jurisprudencia 'Contra Jorge Cosmelli Misle", en Revista de Ciencias Penales NXXXIX, No2 (1987-1989), pp. 118 y ss. En torno al delito de secuestro, BASCUÑÁN RODRÍGUEZ, “Intereses”, cit. nota nº 1, p. 534. 
MALDONADO, Francisco. “Amenazas y coacciones en el Derecho Penal Chileno”.

\section{Caracterización del problema en el derecho chileno}

Conforme a lo dicho, pareciera que la tarea fundamental a realizar consiste en arribar a algún grado de precisión en torno al contenido que opera como referente de protección tras la consagración de las figuras de amenazas y coacciones previstas en el derecho local, sea el mismo o uno diverso en cada una de las hipótesis previstas para cada grupo. Dicha base resulta necesaria para estructurar una interpretación sobre el núcleo esencial de cada modalidad típica, aportando contenidos que favorecen la resolución de los apartados oscuros e incongruencias sistemáticas que ofrece la regulación vigente. Para ello resulta indispensable tener en cuenta la caracterización básica que ofrece el legislador nacional para cada una de las modalidades de conducta señaladas.

El delito de amenazas se regula en el derecho chileno en los artículos 296 y 297 del Código Penal. El legislador no define en forma precisa qué entiende por "amenazar", limitándose a exigir que se trate de una expresión "seria" y "verosímil". Según la doctrina el "amenazar" se vincula a la realización de una "advertencia verbal de la ejecución de un mal"19. En dicha conceptualización no se considera relevante abordar cuestiones asociadas a dicha caracterización básica, como la posibilidad de que la "advertencia" se desarrolle en forma implícita (mediante gestos, por ejemplo) o indirecta (mediante el daño o la afectación de determinados objetos, por ejemplo), o finalmente, si la ejecución del mal que se advierte está previsto para un contexto inmediato ("te voy a matar") o para un futuro relativamente próximo ("si te vuelvo a ver te mataré") ${ }^{20}$.

Las amenazas se penalizan a través de diversas hipótesis comisivas cuya sistemática -en lo esencial $^{21}$ - se estructura a partir de diversos criterios. En la primera disposición mencionada

${ }^{19}$ La idea se expresa en términos equivalentes en MATUS ACUÑA, Jean Pierre y RAMÍREZ G., Cecilia, Lecciones de Derecho Penal Chileno. Parte Especial, Tomo I, Santiago: Edit. Thomson Reuters, 2015, p. 230 ("Dar a entender con actos o palabras que se quiere hacer un mal a otro"). En un sentido análogo ETCHEBERRY, Derecho Penal, cit. nota $\mathrm{n}^{\circ} 12$, T.IV, p. 320. En derecho comparado, por todos, PAREDES CASTAÑÓN, "Libertad", cit., nota n6, p. 367. Asimismo, de forma explícita, OLIVER CALDERÓN, "Consideraciones", cit. nota $\mathrm{n}^{\circ}$ 18, p. 473 (si bien en el contexto del Robo). La limitación de dicha conceptualización en torno a expresiones verbales o "actos de habla" no es sin embargo pacífica. Véase al respecto GUZMÁN DÁLBORA, El delito, cit. nota n², pp. 228 y 229; BASCUÑÁN RODRÍGUEZ, "La regulación", cit. nota n², pp. 295-300 y en BASCUÑÁN RODRÍGUEZ, Antonio, "\&6. Delitos contra la libertad", material inédito asociado a la preparación de un manual destinado al tratamiento de la parte especial del Derecho penal facilitado por el autor, p. 4. En concreto se acepta la idea de que ciertos hechos físicos de diversa naturaleza puedan ser considerados como "amenazas" en la medida que se trate de comportamientos expresivos de una advertencia implícita pero nítida de carácter equivalente. Se menciona como ejemplo la exhibición de un arma de fuego o de un elemento contundente, y la tortura "conminatoria" (destinada a obtener una confesión por miedo a la repetición del dolor). Sobre ello vid asimismo infra nota $\mathrm{n}^{\circ} 134$.

${ }^{20}$ Ambas precisiones son sin embargo relevantes según veremos a lo largo del texto, a pesar de que la doctrina en general les haya restado importancia. Baste tener en cuenta que si se advierte la ejecución inmediata de un mal que en definitiva no se lleva a cabo los efectos de dicho "hecho" se agotan con su realización. Volveremos sobre ello, con detalle, en los últimos apartados de esta contribución.

${ }^{21}$ Existen otros elementos utilizados por el legislador que no resultan determinantes para la determinación de su estructura típica nuclear ni para su sistematización. Así sucede, en las amenazas, con el círculo de personas que pueden ser destinatarios de los males - extensivo al ofendido o a su familia, definiéndose esta última de 
Polít. crim. Vol. 13, № 25 (Julio 2018) Art. 1, pp. 1-41.

[http://www.politicacriminal.cl/Vol_13/n_25/Vol13N25A1.pdf]

(art. 296) el legislador sanciona las amenazas referidas a males constitutivos de delito, diferenciando tres hipótesis alternativas: la mayor penalidad se asigna a dichas amenazas cuando son proferidas en forma condicional y la condición se ha cumplido (art. $296 \mathrm{n}^{\circ} 1$ ); se prevé una pena inferior si esta consecuencia no se produce (art. 296 n²); y una sanción aún menor si la amenaza no se encuentra asociada al cumplimiento de una condición por parte del destinatario (art. 296 n³). En este último caso, se prevé una particular regla de absorción expresa, pues si se llega a ejecutar el "mal constitutivo de delito" se dispone la aplicación exclusiva de la sanción que le corresponda, a menos que con ello se obtenga una pena menor a la prevista para la amenaza "simple". Por su parte el art. 297 se encarga de las amenazas referidas a males no constitutivos de delito, recibiendo sanción sólo en la medida en que se encuentren asociadas a una condición (sea que se encuentre cumplida o frustrada), con una pena equivalente a la prevista para la amenaza condicional de males delictivos no cumplida. Por otro lado, la "coacción" se encuentra regulada en el art. 494 n 16 del Código Penal, sancionándose como falta con una pena de multa. Bajo dicho rótulo se sanciona en exclusiva la coerción consumada (la efectiva constricción del sujeto pasivo para que ejecute o deje de ejecutar un determinado comportamiento) siempre y cuando sea ejecutada mediante "violencia", sin que se considere expresamente bajo dicho rótulo una modalidad equivalente a la coerción mediante amenaza o, si se prefiere, bajo "intimidación". Bajo dicha lectura apegada estrictamente a lo literal pareciera que el doblegar a otro a permanecer postrado en el suelo mediante sujeción física recibe sanción penal, quedando impune esta misma constricción si es obtenida mediante el anuncio de una golpiza. Más extraño aun resultaría el que dicho anuncio podría dar lugar a la aplicación de un delito de amenaza condicional de mal constitutivo de delito, cuyo cumplimiento detonará la aplicación de la pena más grave entre todas las señaladas.

El que esta sistemática y algunas de sus consecuencias más evidentes puedan resultar algo confusas -según acabamos de anticipar- es fruto de diversas causas, originadas -todas- en la asunción de criterios y distinciones inadecuados por parte del legislador. Dichas definiciones impactan, por ejemplo, en el uso de una esquematización de las diversas figuras que resulta equívoca, pues la distinción del carácter delictivo o no delictivo del mal que da forma a la amenaza no constituye una diferenciación esencial, al menos tratándose de las amenazas sujetas a condición. En lugar de ello hubiese sido preferible aludir al carácter condicional o no condicional de la misma, sin que con ello se tengan que modificar las decisiones materiales propuestas, o la propia sistematización y distribución de los correspondientes casos y soluciones previstas. En este sentido, los mismos contenidos ofrecidos por el legislador se pueden estructurar en un esquema diverso que resulta algo más clarificador, a saber:

- La amenaza simple ("no condicional") sólo se sanciona si el mal es constitutivo de delito (art. 296 n³) y si este se lleva cabo no recibe sanción (salvo que de ello se siga un privilegio);

- La amenaza sujeta a condición se sanciona siempre (sea que el mal sea o no constitutivo de delito o incluso si se trata de males "lícitos" con tal que sea impuesta

forma explícita en el inciso final del art. 296-; con los objetos que pueden resultar afectados por aquellos -la propia persona, honra o propiedad del ofendido o de su "familia"-; o, finalmente, con la forma o modalidad "ilegítima" que puede vincular dichos "males" con la eventual exigencia de una condición. 


\title{
MALDONADO, Francisco. “Amenazas y coacciones en el Derecho Penal Chileno”.
}

\author{
"ilegítimamente"), agravándose la pena si la condición se lleva a cabo o si el mal es \\ delictivo (o por ambas razones a la vez). \\ - La coacción solo se sanciona si es ejecutada mediante "violencia".
}

Dicho esto, se debe tener en cuenta que la doctrina local ofrece algún grado de claridad en torno a los contenidos básicos de los casos ubicados en los extremos de dicha estructura. En este sentido se conceptualiza al delito de amenaza simple (o "no condicional") como un atentado que afecta a la seguridad individual ${ }^{22}$ y a la coerción violenta como un atentado que afecta a la libertad de autodeterminación en general ${ }^{23}$. Para ello se tiene en cuenta -en lo fundamental- que en el caso de la amenaza simple no parece posible controvertir que la conducta que se declara punible no se encuentra condicionada o unida a ningún elemento que permita vincular su ejecución con la pretensión de incidir en la voluntad de otro, de forma que no cabe interpretar dicho comportamiento como una forma de incidir sobre la libre realización de actuaciones en un futuro próximo. En ese contexto la única opción que queda la ofrece el riesgo de afectación de sus condiciones de seguridad personal, en tanto es posible advertir la eventualidad de que se llegue a ejecutar el daño (el "mal") que es objeto de la amenaza. Por su parte no se discute que el ejercicio de fuerza física en las coacciones solo se sanciona si ha incidido concretamente en una actuación ajena a voluntad, procediendo con total independencia de la naturaleza o contenido del comportamiento ejecutado y de la constricción efectuada, en la medida en que sea posible calificarla como una modalidad "violenta".

Por el contrario, existe una amplia disparidad de opiniones en torno al tratamiento que cabe dar a los casos de constricción moral, vis compulsiva, intimidación o -si se prefiere- de "amenaza sujeta a una condición”, diferencias que inciden en la propia conceptualización de esta figura en particular como en el tratamiento que cabe dar a la "violencia moral" en el ámbito de las coacciones ${ }^{24}$. En concreto, el problema consiste en determinar si dichos casos deben ser interpretados conforme al estatuto propio de los atentados contra la seguridad individual (esto es, como modalidad agravada o calificada de las "amenazas") o, alternativamente, como actos de coerción, lo que obliga a resolver además la eventualidad de

\footnotetext{
${ }^{22}$ En este sentido, ETCHEBERRY, Derecho Penal, cit. nota no 12, T. IV, p. 319 y 320; MATUS ACUÑA y RAMÍREZ Lecciones, cit. nota n¹9, p. 209; NOVOA MONREAL, Eduardo, "Cuestiones jurídicas relativas al delito de amenazas", en Revista de Ciencias Penales, segunda época, Tomo XII, no 1 y 2, Enero - Junio (1950), pp. 15 a 23, p. 23. En la doctrina comparada más tradicional esta asunción resulta discutible, en especial, por la relación que se establece por ciertos sectores doctrinales entre el quebrantamiento de la seguridad y su incidencia en la libertad de desempeño del individuo. Para una panorámica sintética del desarrollo ofrecido en el siglo XX en Alemania, Italia y España véase LORENZO SALGADO, "El delito", cit. nota n 17, pp. 286 a 301. La única excepción en el derecho chileno -que rompe dicha unanimidad- en relación a ambos puntos la ofrece MATUS ACUÑA y RAMÍREZ Lecciones, cit. nota n¹9, pp. 220, 222 y 229.

${ }^{23}$ En este sentido, por todos, ETCHEBERRY, Derecho Penal, cit. nota $\mathrm{n}^{\mathrm{o}} 12$, T. III, p. 245; LABATUT GLENA, Gustavo, Derecho Penal, Tomo II, $7^{\text {a }}$ edición actualizada por el profesor Julio Zenteno V., Santiago: Edit. Jurídica de Chile, 1996, p. 32. Lo propio sucede en el caso del derecho español LORENZO SALGADO, "El delito", cit. nota n' 17, p. 253; MIRA BENAVENT, "El concepto", cit. nota n' 10, p. 120.

${ }^{24}$ BASCUÑÁN RODRÍGUEZ, "La regulación”, cit. nota n², p. 192 comparte el papel central que juega la adscripción de esta figura en la determinación de los bienes jurídicos y la interpretación que cabe dar a la sistemática general de estos grupos de delitos.
} 
Polít. crim. Vol. 13, № 25 (Julio 2018) Art. 1, pp. 1-41.

[http://www.politicacriminal.cl/Vol_13/n_25/Vol13N25A1.pdf]

que dichos supuestos -todos o algunos, y cuáles- puedan llegar a ser considerados como casos de "violencia" a los efectos de la interpretación de la falta de coacciones.

De esta determinación dependen una serie de consecuencias dogmáticas ${ }^{25}$. En el primero de esos casos, se debiera concluir que el hecho delictivo se consuma con la sola emisión de las expresiones correspondientes ${ }^{26}$; que el dolo típico se orienta a la causación del mal o, si se prefiere, que es equivalente al que se exige para el hecho consumado ${ }^{27}$; que la "seriedad" y la "verosimilitud" que se exigen para calificar dicha conducta se vinculan a la concreción de un riesgo efectivo para la seguridad de la víctima ${ }^{28}$; que se deben referir los "males" a

${ }^{25}$ Parte de ellas ya se anticiparon en nuestro medio -en forma fundacional, hasta donde alcanzamos a advertirpor parte de NOVOA MONREAL, "Cuestiones jurídicas", cit., nota $\mathrm{n}^{\circ} 22$, pp. 16 y 17 . Con respecto a las amenazas condicionales, concretamente, en p. 21. Cabe advertir que, en opinión de BASCUÑ̂́N RODRÍGUEZ, “La regulación”, cit. nota n², p. 288, la incertidumbre que rodea a la precisión del bien jurídico referido a la "seguridad" (propio de las amenazas simples) hace que dichas definiciones sean bastante aleatorias, en tanto las diversas posturas llevan a sostener consecuencias que en algunos casos son diversas respecto a las que se formulan en el texto. En el mismo sentido JAREÑO LEAL, Las amenazas, cit. nota nº 17, p. 20.

${ }^{26}$ BASCUÑÁN RODRÍGUEZ, "La regulación”, cit. nota n², p. 198. De ahí que Guzmán Dálbora califique a las amenazas, a partir de su sistematización, como un delito “de expresión”. Véase GUZMÁN DÁLBORA, El delito, cit. nota n², p. 172 y, en general, en pp. 166-180. Advierte sin embargo que, por esta misma razón, el delito debe entenderse consumado cuando el destinatario de las amenazas las puede percibir o advertir, lo que en algunos casos supone que dicho hito acontece en un momento posterior (pp. 198, 462 a 464). Con respecto a cómo opera esta conceptualización en el caso de las amenazas condicionales, véanse las pp. 183 y ss.

${ }^{27}$ Véase al respecto, BASCUÑÁN RODRÍGUEZ, “La regulación”, cit. nota n², pp. 286. Guzmán Dálbora rechaza esta conceptualización en base a una argumentación que se grafica adecuadamente en el siguiente ejemplo que propone a los mismos efectos: "no se amenaza con dolo homicida, sino con dolo de amenazar" (GUZMÁN DÁLBORA, El delito, cit. nota n², p. 270). El dolo encuentra su objeto en la aptitud de las expresiones proferidas en cuanto idóneas para la provocación de una determinada cuota de inseguridad (pp. 418 y 419) y por ello -siguiendo a NOVOA MONREAL, "Cuestiones jurídicas", cit., nota n ${ }^{\circ} 22-$ no es necesario en modo alguno el real propósito de llegar a consumar el mal delictivo, ni la "persistencia en dicho propósito" o la premeditación como sugiere otro sector de la doctrina (p. 269). Entiende que la comprensión mayoritaria no es más que un resabio de la conceptualización de las amenazas como actos preparatorios de los respectivos delitos (p. 269). Se podrá advertir que para este autor el dolo presenta una estrecha relación con las exigencias de seriedad y verosimilitud, las que se muestran prácticamente como una ratificación de dicha idoneidad. Al respecto NOVOA MONREAL, "Cuestiones jurídicas”, cit., nota n 22, pp. 424 y 425 . En una postura intermedia se inscribe MATUS ACUÑA y RAMÍREZ Lecciones, cit. nota nº19, p. 235, quienes entienden que el referente en este caso apunta al mal en el sentido de la doctrina mayoritaria, pero se extiende también a la condición, en forma simultánea, en el caso de la amenaza condicional.

${ }^{28}$ Para una síntesis de las opiniones dominantes véase GUZMÁN DÁLBORA, El delito, cit. nota n², pp. 267 y ss. La comprensión de esta exigencia admite dos variantes pues puede referirse al riesgo para la concreta situación de seguridad de la víctima -analizada en forma objetiva- o en relación a la eventualidad de que ésta perciba una condición o posición de inseguridad. En el primer caso "serio" se vincula a la real decisión del autor de llevar a cabo el mal (el propósito efectivo) y "verosímil” se asocia a que sea posible -objetivamente, desde la perspectiva de un observador imparcial- su concreción. Esta es la doctrina dominante al respecto. Al respecto BASCUÑÁN RODRÍGUEZ, “La regulación”, cit. nota n², p. 286. Desde la segunda perspectiva -sostenida por ejemplo por Guzmán Dálbora- es irrelevante que el ejecutor "quiera realmente lo que declara" en la medida que las expresiones se hayan expresado en condiciones que el receptor interpreta como reales (GUZMÁN DÁLBORA, El delito, cit. nota n², p. 272). "Serio" es por ello -para este autor- una exigencia asociada a la credibilidad que objetivamente le puede dar la víctima a las expresiones proferidas y "verosímil" es una exigencia que afianza esta misma calificación: la "apariencia de seriedad" (p. 277). El análisis es por ello individualizador, a realizarse desde la perspectiva del concreto sujeto pasivo, pues lo relevante es la idoneidad de las amenazas para incidir o afectar la tranquilidad o seguridad de la posición jurídica de la víctima y no para la concreción del peligro que anuncia. Al respecto véase también BASCUÑÁN RODRÍGUEZ, "La regulación”, 


\section{MALDONADO, Francisco. “Amenazas y coacciones en el Derecho Penal Chileno”.}

contenidos ilícitos o, de preferencia, punibles $^{29}$; y, por esta misma razón, que la eventual concreción futura de dicho daño (punible) amerita una cláusula de absorción (en tanto lleva a identificar la amenaza como "acto anterior copenado") ${ }^{30}$. Por su parte, la conceptualización de dicha conducta como un acto de coerción lleva a identificar la consumación con la realización o cumplimiento por parte de la víctima de la respectiva condición impuesta ${ }^{31}$; a vincular el dolo con el contenido de dicha condición (y no en relación al "mal" que da contenido a la amenaza) ${ }^{32}$; a referir la seriedad y verosimilitud en torno a la perspectiva del sujeto pasivo (en tanto idónea para incidir en su motivación para resolver cómo actuar) ${ }^{33}$; a referir los males a contenidos que pueden perfectamente ser lícitos (en la medida que sean impuestos ilegítimamente) ${ }^{34}$; y a sostener una hipótesis concursal en caso en que se llegue a ejecutar el mal, teniendo en cuenta que se afectará el correspondiente bien jurídico al que dicho mal se asocia además de la propia libertad de autodeterminación de la víctima.

Dicho esto, se debe tener en cuenta que la idea de que la amenaza condicional se debe conceptualizar como un atentado a la seguridad se ve favorecida por el hecho de que su consumación se encuentra asociada al solo evento de su emisión (arts. $296 \mathrm{n}^{\circ} 1$ y 2) ${ }^{35}$, y porque se trata de una conducta que recibe una sanción superior a la prevista para la coacción violenta (que solo es penada como falta). Hay que tener en cuenta a este respecto que no parecen existir razones que justifiquen dicha diferenciación (entre violencia e intimidación o amenaza) si ambas figuras constituyeran efectivamente dos formas o modalidades

cit. nota n², p. 286 con especial referencia a la relación de esta conceptualización con la exigencia de idoneidad para la provocación de "temor" en la víctima, relevante de considerar en cuanto constituye la alternativa más "individualizadora" o subjetivista entre las propuestas históricamente. Una conceptualización intermedia o mixta se puede advertir en MATUS ACUÑA y RAMÍREZ Lecciones, cit. nota n ${ }^{\circ} 19$, p. 231 , alternativa que dificulta diferenciar la seriedad del dolo específico de la figura.

${ }^{29}$ BASCUÑÁN RODRÍGUEZ, "La regulación", cit. nota n², p. 287. A este respecto GUZMÁN DÁLBORA, El delito, cit. nota $\mathrm{n}^{\circ} 2$, p. 295, destaca que, en los modelos italiano, suizo y austriaco, de forma excepcional se considera la posibilidad de sancionar la sola amenaza simple -y por ello, con mayor razón la condicionalincluso si el mal recae en hechos ilícitos que carecen de calificación como delitos, lo que se presenta como un extremo en dicho modelo. Lo relevante a dicho respecto es tener en cuenta que resulta difícil justificar la penalización de la mera advertencia de males que en sí mismos carecen de relevancia penal.

${ }^{30}$ GUZMÁN DÁLBORA, El delito, cit. nota no2, p. 502.

${ }^{31}$ BASCUÑÁN RODRÍGUEZ, "La regulación", cit. nota n², p. 198.

32 JAREÑO LEAL, Las amenazas, cit. nota $\mathrm{n}^{\circ}$ 17, p. 32.

${ }^{33}$ Por todos BASCUÑÁN RODRÍGUEZ, "La regulación”, cit. nota n², p. 286. Mientras el dolo se remite a la concreción de la coerción (es decir, al cumplimiento de la condición), las exigencias de seriedad y verosimilitud se asocian, concreta respectivamente a la "idoneidad coercitiva" y a la "credibilidad". También BASCUÑÁN RODRÍGUEZ, "El Robo", cit. nota n4, p. 105. Conviene tener en cuenta que desde esta perspectiva es irrelevante la "real intención del agente de llevar a cabo el mal" o la "provocación de temor en el destinatario" (pues puede operar la constricción en base a una decisión de conveniencia).

${ }^{34}$ BASCUÑÁN RODRÍGUEZ, "La regulación", cit. nota n², p. 287. FERNÁNDEZ DIAZ, Alvaro, "Amenaza de difundir información íntima: El caso que afectó al Conservador de Bienes Raíces de Santiago", en Revista Chilena de Derecho, vol. 35 nº (2008), pp. 183 a 191, p. 185, en referencia a males no delictivos y en pp. 188 y ss., sobre males lícitos.

${ }^{35} \mathrm{Al}$ respecto BASCUÑÁN RODRÍGUEZ, "La regulación", cit. nota n², p. 306 sugiere que de alguna manera esta determinación es irrelevante a nivel material pues existen buenas razones para que legislador se incline por cualquiera de las opciones. A favor de la mera actividad, destacan razones preventivas mientras que a favor del resultado coactivo se encuentra la tendencia -razonable- de catalogar y estructurar los delitos a partir de la lesión del interés comprometido (dejando para el iter críminis los casos de tentativa). 
Polít. crim. Vol. 13, № 25 (Julio 2018) Art. 1, pp. 1-41.

[http://www.politicacriminal.cl/Vol_13/n_25/Vol13N25A1.pdf]

alternativas y equivalentes de la misma infracción, centradas por ello en la protección de la libertad de autodeterminación ${ }^{36}$. Incluso más, se ha destacado - con acierto- el que resultaría contradictorio que la mera "advertencia de un mal futuro" orientada a forzar la voluntad de la víctima constituya una conducta más gravosa que la actuación física que efectivamente logra constreñir su decisión, considerando que el "riesgo de daño" necesariamente amerita un desvalor inferior a la "provocación efectiva" del mismo ${ }^{37}$. Por su parte, la tesis opuesta se ve favorecida por el hecho de que la extensión de los males que pueden ser objeto de la amenaza (delictivos, no delictivos e incluso "lícitos", cuando son impuestos "ilegítimamente") no se encuentran limitados a aquellos que presentan relevancia penal ${ }^{38}$, teniendo en cuenta que no resulta sensato sostener que se puede proteger penalmente un riesgo concreto de lesión cuya concreción como hipótesis de daño carece de dicha calificación ${ }^{39}$. Pero también se apoya dicha asunción -a nuestro juicio de forma determinante- en el hecho que el legislador solo prevé una regla de absorción expresa para aquellos casos en que se ejecuta el mal -por supuesto, delictivo- que ha sido objeto de una amenaza previa cuando se trata del delito de amenazas simples (no condicionales), ofreciendo una solución de texto expreso que favorece - a contrario sensu- una respuesta concursal para los casos en que ello ocurre con respecto a una amenaza condicional ${ }^{40}$. Así, el ex marido que

\footnotetext{
${ }^{36} \mathrm{Al}$ respecto BASCUÑÁN RODRÍGUEZ, "El Robo", cit. nota nº, p. 101.

${ }^{37}$ En este sentido ETCHEBERRY, Derecho Penal, cit. nota $n^{\circ}$ 12, p. 245. Le siguen GUZMÁN DÁLBORA, El delito, cit. nota no2, p. 140 y 141; MATUS ACUÑA y RAMÍREZ, Lecciones, cit. nota nº19, p. 228. Lo destaca asimismo BASCUÑÁN RODRÍGUEZ, "La protección", cit. nota n², p. 17 (señala en forma elocuente que: "pasar del dicho al hecho tiene menos pena").

${ }^{38}$ Por todos BASCUÑÁN RODRÍGUEZ, "La regulación”, cit. nota n², p. 215.

39 Por todos BASCUÑÁN RODRÍGUEZ, "La regulación", cit. nota n², p.198. En su tiempo NOVOA MONREAL, "Cuestiones jurídicas", cit., nota $\mathrm{n}^{\circ} 22$, p. 18, lo ocupó como argumento para sostener que la amenaza condicional no puede por ello estar referida a la protección de la seguridad individual agregando que ello supondría asociar su contenido de injusto del que detenta el mal, lo que en estos casos sería imposible si este último no es punible. Coherentemente, explica de esta forma el por qué la amenaza simple solo se considera punible si el mal tiene precisamente carácter delictivo (p. 23). Lo relevante en este caso es por ello el modo de imposición (ilegítimo) del mal "lícito" (p. 18). De ahí que critique el que nuestra regulación -original- limite la consideración de los "males" a aquellos que fuesen "ilícitos", lo que en definitiva se corrige en una modificación legal introducida por la ley 19.659. También Bustos entiende que la imposición de males lícitos es determinante como indicativo de que el referente de protección es la libertad (p. 98), vinculado a una eventual desconexión entre condición y amenaza (p.98 y, previamente, si bien en relación a un punto diverso, en p. 96). A pesar de ello este autor entiende que el contenido de injusto de las amenazas simples no está asociado al carácter delictivo del mal, sin ofrecer mayor desarrollo de sustento. Al respecto BUSTOS RAMÍREZ, Juan, Manual de Derecho Penal. Parte especial, $2^{\mathrm{a}}$ ed. Aumentada, corregida y puesta al día, Barcelona: Ariel Derecho, 1991, p. 97.

${ }^{40}$ Las referencias a este respecto son en general escasas en la literatura. Manifiestan una conclusión diversa Matus y Ramírez, quienes entienden que es irrelevante la consagración de dicha regla en tanto la absorción operaría siempre, por el hecho de que todos los casos constituirían un concurso aparente de leyes que se resuelve por aplicación del principio de consunción. Bajo dicha óptica la amenaza siempre sería un "acto anterior copenado". Al respecto véase MATUS ACUÑA y RAMÍREZ, Lecciones, cit. nota nº19, p. 236. Por su parte GUZMÁN DÁLBORA, El delito, cit. nota n², p. 503 se manifiesta a favor de advertir un concurso, pero solo cuando se trata de una amenaza no condicional asociada a un delito que reciba una pena menor (p. 504). Hay que tener en cuenta que la opinión de este último autor se basa en el texto original de la regulación prevista en el Código, la que consagraba la cláusula aludida precisamente para el caso de la "amenaza de mal constitutivo de delito de carácter condicional y que se encontrare cumplida" y no en relación a la amenaza de carácter simple referida a los mismos males como es en la actualidad. Si bien dicha postura parece atendible bajo las premisas que dan origen al planteamiento de ambos autores (libertad y seguridad son dos expresiones del mismo bien jurídico) resulta difícilmente compatible con el mayor desvalor asociado a la amenaza coercitiva -que
} 
MALDONADO, Francisco. "Amenazas y coacciones en el Derecho Penal Chileno”.

advierte a su ex mujer que "si la vuelve a ver con otro hombre en su antigua casa la va a golpear", y que lleva a cabo dicha acción a la semana siguiente bajo la creencia de que ella ha incumplido dicha advertencia, realiza acciones que atentan contra su libertad (la amenaza condicional) y además en contra de su integridad (las lesiones), debiendo por ello aplicarse la pena correspondiente a la sanción de ambas figuras delictivas.

Finalmente hay tener en cuenta -como dato adicional, muy relevante- que la sistemática que ofrece nuestra regulación vigente es fruto de una serie de modificaciones de carácter específico que fueron introducidas en la regulación de las amenazas en el año 1999 a través de la ley 19.659. Hasta dicha fecha, la estructura de las amenazas había conservado sus definiciones originales. Lo relevante radica en que resulta posible identificar tras los contenidos reformados una clara tendencia a favor de la tesis que identifica la amenaza condicional como una forma de coerción, contrario a como sucede con la regulación original.

\section{Tratamiento dogmático de la amenaza condicional en el derecho chileno}

En la doctrina nacional vigente José Luis Guzmán Dálbora, Jean Pierre Matus y María Cecilia Ramírez defienden en forma muy decidida la tesis que identifica la amenaza condicional como una forma de atentado a la seguridad individual (agravada) ${ }^{41}$. La tesis contraria -que asocia su fundamento con la protección de la libertad de autodeterminación individual- es a su vez sostenida por Antonio Bascuñán Rodríguez, Juan Pablo Mañalich y, con matices, por parte de Alfredo Etcheberry y -en su tiempo- por Eduardo Novoa Monreal ${ }^{42}$. Revisaremos a continuación los aspectos medulares de estos planteamientos.

\subsection{La amenaza condicional como atentado a la seguridad individual}

refleja una consideración independiente del atentado a la libertad de autodeterminación que ello supone) y sobre todo con la limitación expresa que propone el texto legal, en tanto se asocia dicha cláusula solo a una determinada hipótesis comisiva. Más aun, el hecho de que el legislador la haya desplazado de lugar mediante la modificación introducida por la Ley 19.659 -aplicándola a un caso diverso, pero conservando su previsión específica- pareciera una manifestación inequívoca de que no la concibe como una solución por defecto, aplicable a todos los casos. De ser así lo lógico habría sido optar por su supresión o, en su caso, por una regulación generalizada aplicable a todos los casos. De ahí que la interpretación propuesta resulte incompatible con el texto expreso de la ley.

${ }^{41}$ También es posible identificar una tesis similar en el tratamiento que ofrece Jorge Mera de las amenazas y coacciones, en particular, MERA FIGUEROA, Hurto y Robo, cit. nota $\mathrm{n}^{\circ} 18$, pp. 135. Más allá que, en ocasiones -y de forma indistinta y poco regular- dicho autor vincule ambas figuras (en conjunto) con la protección de la libertad de obrar (MERA FIGUEROA, Hurto y Robo, cit. nota $\mathrm{n}^{\circ}$ 18, pp. 118,119, 138 y 139) todo indica que lo hace en referencia exclusiva a las coacciones, reconociendo que el legislador le asigna un escaso desvalor. Esta misma impresión sobre las opiniones de Mera ofrece BASCUÑÁN RODRÍGUEZ, "El Robo", cit. nota $\mathrm{n}^{\circ} 4$, pp. 105 y ss. Cabe tener en cuenta que solo Matus y Ramírez ofrecen una interpretación que tiene en cuenta el texto positivo actualmente vigente. Con ello, las opiniones expuestas por Guzmán Dálbora -que de hecho son las más completas, en cuanto propuestas a través de una obra monográfica dedicada al tratamiento de las amenazas- no consideran las modificaciones introducidas por la ley 19.659 y que, según advertimos, parecieran favorecer la tesis de que las amenazas condicionales se orientan al amparo de la libertad de autodeterminación individual.

42 También es posible identificar una tesis similar en el tratamiento que ofrece FERNÁNDEZ DIAZ, “Amenaza", cit. nota nº 34, p. 185. 
Para Guzmán Dálbora el modelo instaurado en el Código chileno muestra claros signos de encontrarse vinculado a la tradición propia del régimen francés, continuada en el derecho español que, para dicho autor, se adscribe al mismo tipo de modelo ${ }^{43}$. Lo constata -entre otros antecedentes- a partir de la enorme dispersión de figuras punibles que en términos específicos protegen expresiones concretas de la libertad de obrar o de actuación del individuo $^{44}$, asumiendo que esta decisión del legislador se vincula a la idea -atribuida a Lisztde que la libertad - como referente de protección- sólo se lesiona a partir de sus expresiones específicas, tan disímiles como las posibilidades de actuación humana ${ }^{45}$. Si bien dicha opción debiese ir acompañada de la total ausencia de consideración de una regulación genérica de la coerción - cosa que no ocurre en Chile, ni en la codificación española original- el que su consagración de cuenta de una consideración bastante modesta sobre su desvalor propio es interpretado más bien como un elemento que respalda dicha tesis, bajo la idea de que es un "tipo de recogida" -subsidiario, con carácter general- que por ello no puede tener prevista una pena superior que los restantes atentados ${ }^{46}$. El efecto que extrae de ambas consideraciones es que las amenazas necesariamente debiesen dar cuenta de un contenido adicional y diverso al que ofrece la necesidad de tutela penal de la libertad de obrar ${ }^{47}$. Aclara asimismo que dicha conclusión no discrimina entre las amenazas condicionales y las simples, recurriendo para ello a la gráfica sistemática que ofrece el tratamiento positivo consagrado en el código original y a la inconsistencia penológica que supondría la opción contraria: la baja pena de la coacción resulta incompatible con la decisión de imponer a la amenaza condicional el régimen penológico más gravoso entre todos los previstos ${ }^{48}$. Bajo dicha conceptualización, el obligar a otro a ingerir una bebida alcohólica que no desea por medio de la fuerza física no podría tener una pena tanto menos gravosa que la aplicable a quien se limita a advertir a otro que lo va a golpear si no se toma esta misma bebida, si este último comportamiento fuese penalizado en función de la lesión de la libertad de autodeterminación que supone. Guzmán Dálbora decanta, por ello -en términos constructivos-, a favor de la tesis que identifica el fundamento de la amenaza en torno a la protección de un bien jurídico

\footnotetext{
${ }^{43}$ GUZMÁN DÁLBORA, El delito, cit. nota n², p. 69. Sobre el desarrollo de la regulación española conforme a dicha comprensión véanse las pp. 71 a 74, complementadas con el tratamiento ofrecido por la dogmática española próxima a la codificación en pp. 91 y ss. y, entre autores más próximos a la segunda mitad del siglo XX en pp. 94 y ss., incluyendo a aquellos que identifican el objeto de protección en torno a la libertad individual. ${ }^{44}$ GUZMÁN DÁLBORA, El delito, cit. nota n² y, con amplio detalle en pp. 135 a 137. Dicho desarrollo va precedido de un lato tratamiento de la conceptualización de dicho objeto de tutela y las dificultades que enfrenta su precisión (pp. 118 a 134). En un sentido similar, MIRA BENAVENT, "El concepto", cit. nota n 10, pp. 120 y ss. Sobre la influencia de la regulación francesa sobre el Código Penal español de 1822, y su evolución en las propuestas posteriores de codificación, LARRAURI, Libertad, cit. nota nº 17, pp. 21 a 24.

${ }^{45}$ GUZMÁN DÁLBORA, El delito, cit. nota n²2, pp. 134 y 135. Tras dicha concepción subyace la idea de que tras la mayoría de los delitos se puede identificar algún tipo de afectación de la libertad de los individuos. Sobre ello ETCHEBERRY, Derecho Penal, cit. nota n ${ }^{\text {12 }}$, T. III, p. 196, si bien no llega a sostener sobre esa base el que carece de relevancia independiente. En concreto, circunscribe su tratamiento autónomo a aquellos casos en que "se afecta la autodeterminación sin incidir en otro derecho ulterior".

${ }^{46}$ GUZMÁN DÁLBORA, El delito, cit. nota n², pp. 137 y 138.

${ }^{47}$ GUZMÁN DÁLBORA, El delito, cit. nota n², pp. 137 a 139. En el mismo sentido MIRA BENAVENT, "El concepto", cit. nota n' 10, p. 121 y 128.

${ }^{48}$ GUZMÁN DÁLBORA, El delito, cit. nota n², pp. 140 y 141.
} 
diverso, radicado en la seguridad individual ${ }^{49}$. Para ello -en lo esencial- destaca las razones que favorecen la necesidad de tutela y relevancia social de la seguridad individual como objeto de protección penal, en una construcción estrechamente asociada al respeto y protección que cabe dar al estatus jurídico de la persona y a las garantías que inciden en la condición jurídica del individuo ${ }^{50}$. La seguridad individual aparece por ello conectada funcionalmente con las posibilidades de participación y actuación, en tanto concluye que un déficit en las condiciones asociadas a la seguridad individual incide negativamente en la propia posibilidad de ejercicio de la libertad ${ }^{51}$. Dicha base le permite asimismo sostener que se trata de un interés que detenta una mayor relevancia y prioridad a la hora de analizar las necesidades y razones de mérito que decantan en su protección penal ${ }^{52}$. La amenaza condicional es por ello para este autor -esencialmente- un delito contra la seguridad, agravado por el quebrantamiento (potencial o efectivo) de su libertad concreta de actuación, que se agrega a la afectación de su libertad en general que proviene de la inseguridad provocada $^{53}$.

Estas premisas son plenamente compartidas por los profesores Matus y Ramírez, quienes incluso llevan al extremo las respectivas consecuencias. Coinciden en la conceptualización de la condición potencialmente concurrente en las amenazas como una razón suficiente para justificar un caso o modalidad "agravada" de comisión, sin que por ello constituya un elemento que modifique su naturaleza propia. También coinciden en el nexo y preponderancia que se reconoce a la seguridad como presupuesto basal de la libertad ${ }^{54}$ y con la idea de que todos los delitos asociados a la protección de la libertad apuntan también, y preferentemente, al amparo de la seguridad personal ${ }^{55}$. Agregan a ello que las decisiones penológicas propuestas por el legislador solo se podrían explicar bajo el supuesto de que se trata de figuras que se orientan a la protección de la seguridad, teniendo en cuenta dos aspectos complementarios: primero, pues su estructura sistemática se centra en la gravedad

${ }^{49}$ GUZMÁN DÁLBORA, El delito, cit. nota nº, pp. 141 y ss. Descarta asimismo la relevancia y pertinencia de la seguridad pública o general como referente alternativo por razones que igualmente se encuentran vinculadas al contexto histórico, haciéndose cargo al mismo tiempo del problema de indeterminación que ofrece la seguridad como bien jurídico penal. Al respecto véase el desarrollo propuesto en pp. 144 a 156.

${ }^{50}$ GUZMÁN DÁLBORA, El delito, cit. nota no2, p. 505.

${ }^{51}$ GUZMÁN DÁlBORA, El delito, cit. nota no 2, pp. 158 y 159. Sobre los orígenes históricos de esta virtual asimilación de libertad y seguridad LARRAURI, Libertad, cit. nota n ${ }^{\circ} 17$, pp. 59 a 65. Sobre el nexo entre la provocación de temor y la afectación de la tranquilidad para decidir a voluntad, JAREÑO LEAL, Las amenazas, cit. nota $\mathrm{n}^{\circ} 17$, p. 24.

${ }^{52}$ De esta forma justifica el tratamiento prevalente que se asigna a su afectación expresado particularmente en las diferencias penológicas que existen entre las amenazas y las coacciones.

${ }^{53}$ Conforme a dicha estructura esta afectación de la libertad provoca una concreta incidencia sobre la seguridad del individuo, haciéndola en definitiva "más intensa". De ahí que el plus de lesividad que justifica la mayor penalidad se ubique desde este punto de vista en torno al mismo bien jurídico (mediatizado por la afectación, mas intrascendente, de la libertad). Con más detalle GUZMÁN DÁLBORA, El delito, cit. nota n², p. 265. En forma coherente con dicha calificación GUZMÁN DÁLBORA, El delito, cit. nota n², p. 264 identifica el tipo básico de las amenazas en torno a la amenaza simple prevista en el artículo $296 \mathrm{~N}^{\circ} 3$ del Código Penal.

${ }^{54}$ MATUS ACUÑA y RAMÍREZ, Lecciones, cit. nota nº 19, pp. 219 y 220. Los matices a este respecto son sin embargo relevantes pues en este caso se defiende la tesis de que la protección de la seguridad individual se vincula a "las condiciones físicas de la existencia del individuo", abarcando un contenido más amplio que el ofrecido por su "estatus jurídico" (en el sentido sostenido por Guzmán Dálbora).

${ }^{55}$ MATUS ACUÑA y RAMÍREZ, Lecciones, cit. nota no 19 , pp. 220 y 222. 
Polít. crim. Vol. 13, № 25 (Julio 2018) Art. 1, pp. 1-41. [http://www.politicacriminal.cl/Vol_13/n_25/Vol13N25A1.pdf]

del "mal" con que se amenaza y segundo, por el hecho de que asumen que la afectación de la libertad no admitiría ningún tipo de graduación ${ }^{56}$. Sobre dicha base llegan a sostener -en lo más relevante y contra la doctrina uniforme- que las coacciones también afectan a la seguridad individual ${ }^{57}$, asignándoles una función como tipo básico, de recogida o subsidiario de carácter general, incluso aplicable respecto de las propias amenazas ${ }^{58}$. Bajo dicho esquema las diferencias entre ambas figuras se limitan a una cuestión de entidad, adscribiendo los casos de advertencia coercitiva de males de mayor gravedad al ámbito propio de las amenazas y los casos de "fuerza moral" referido a males de escasa significación a la sanción ofrecida para las coacciones ${ }^{59}$, aportando con ello una interpretación de carácter extensivo o altamente

${ }^{56}$ MATUS ACUÑA y RAMÍREZ, Lecciones, cit. nota nº19, p. 220. En contra, BASCUÑÁN RODRÍGUEZ, "El Robo", cit. nota n4, p. 104 y 108, si bien coincide en lo referido a los casos que califican como "vis absoluta" (p. 110). La observación parece pasar por alto dos consideraciones relevantes. En primer lugar, el que existen otros criterios que pueden incidir en la calificación de la gravedad de las amenazas, como su carácter anónimo o su expresión a través de medios escritos. Al respecto véase el desarrollo propuesto por GUZMÁN DÁLBORA, El delito, cit. nota n², pp. 33 y 334, y en CARRARA, Francesco, Programa de Derecho Criminal, Parte especial, Volumen II, Bogotá (Colombia): Temis, 1986, pp. 362, 363 y 367 (Aptdo. 1579); BASCUÑÁN RODRÍGUEZ, "La protección", cit. nota n², p. 17. Por otro lado -y lo más relevante- el que tanto en doctrina como a través de la legislación se puede advertir que es perfectamente posible "graduar" la gravedad de los casos a partir de la entidad de la afectación de la libertad. Se le puede atribuir una entidad variable, en primer lugar, según cuál fuese la clase o naturaleza de la facultad sobre la que recae su ejercicio (expresiones de la sexualidad, desplazamiento, etc.), siendo también posible atribuir un significado de entidad diverso a la coerción en función del tiempo que la caracteriza, teniendo en cuenta que la constricción inminente reduce las posibilidades de evitación (en este sentido BASCUÑÁN RODRÍGUEZ, "La regulación", cit. nota n², p. 296; MIRA BENAVENT, "El concepto", cit. nota ${ }^{\circ} 10$, pp. 155 y 156). En el mismo sentido BASCUÑÁN RODRÍGUEZ, "El Robo", cit. nota nº, pp. 104 y 105, agregando además a la propia entidad del mal como criterio de conmensurabilidad (al menos en lo referido a la vis compulsiva). Finalmente, la fijación de la afectación de la libertad de un individuo en un punto específico obedece a su estructuración bajo un estándar de exigencia, presentando en términos naturales un carácter graduable. En este sentido, en la mayoría de los atentados a la libertad de autodeterminación no se exige una completa anulación de las facultades de la víctima, sino que corresponde a una reducción de sus competencias para actuar, motivarse, etc., más allá del margen que se define como exigible respecto de cualquiera. Sobre ello véase el análisis referido a las exigencias "cuantitativas" de afectación de la libertad que propone MIR PUIG, Santiago, "El delito", cit. nota n 15, pp. 288 y ss. Si bien lo refiere a la interpretación de la exigencia de "violencia" en las coacciones, se trata de un contenido análogo al referido en las líneas precedentes.

${ }^{57}$ Esta asunción cruza el texto y las interpretaciones ofrecidas por estos autores, más allá de que a nivel introductorio ofrecen una conceptualización más acorde a la doctrina dominante. En efecto en MATUS ACUÑA y RAMÍREZ, Lecciones, cit. nota n ${ }^{\circ} 19$, p. 209 sostienen las coacciones son atentados a la libertad y que se diferencian de las amenazas por constituir estos últimos ataques a la seguridad del individuo. En un sentido equivalente, otros autores han llegado a sostener -en el extremo opuesto, y bajo diversas fórmulas- que las amenazas simples también afectan a la libertad de autodeterminación. Al respecto, con más detalle sobre las diversas propuestas, LARRAURI, Libertad, cit. nota n 17, pp. 226 a 233.

${ }^{58}$ Específicamente sostienen que las coacciones "integran" las amenazas, en tanto figura subsidiaria. MATUS ACUÑA y RAMÍREZ, Lecciones, cit. nota nº 19 , pp. 222 y 227. En un sentido equivalente -pero no idénticoBUSTOS RAMÍREZ, Manual, cit. nota ${ }^{\circ} 39$, p.103 (si bien recurre a la entidad del resultado lesivo y de la conducta -violencias- como criterios complementarios), criticando la opción de ocupar como baremo a uno solo de ellos.

${ }^{59}$ MATUS ACUÑA y RAMÍREZ, Lecciones, cit. nota n ${ }^{\circ} 19$, pp. 225 y 228 . Alude para ello expresamente a la "naturaleza subsidiaria" de las coacciones. En una línea equivalente -si bien no igual- BUSTOS RAMÍREZ, Manual, cit. nota ${ }^{\circ}$ 39, p. 97 sostiene que amenazas condicionales y coacciones ofrecen una relación de consunción que debe ser resuelta por la pena superior. La propuesta debe resolver numerosos problemas. Aparte de las razones de texto positivo (véase nota siguiente) resulta complejo sostener que la advertencia de males de escasa entidad puede constituir una constricción idónea para forzar la voluntad, ubicándose bajo el umbral 


\title{
MALDONADO, Francisco. “Amenazas y coacciones en el Derecho Penal Chileno”.
}

\author{
“espiritualizada" de la expresión "violencia” que caracteriza al medio comisivo de la \\ coacción ${ }^{60}$.
}

A nuestro juicio las razones expuestas no son del todo convincentes, sin perjuicio de coincidir en el diagnóstico referido al contexto histórico y las fuentes que parecieran haber influido decisivamente en la regulación original consagrada en Chile ${ }^{61}$. También reconocemos que

mínimo exigible. Por sobre aquél, resulta complejo establecer diferencias, en la medida en que en todos esos casos se puede afirmar que "no hay voluntad" o, cuando menos "que no hay voluntad libre".

${ }^{60}$ En lo central se procura ampliar la concepción de lo que se entiende por "violencia", más allá de lo físico, a fin de dar a ciertos casos de "fuerza" o "violencia" moral o inmaterial el mismo tratamiento que tienen las coacciones. Este tipo de interpretaciones constituyen una constante en el derecho comparado y se estructuran con el fin de resolver la disparidad penológica que presenta el tratamiento de las coerciones violentas efectivas (consumadas) en comparación con el asignado a las amenazas condicionales. Lo constata como práctica en torno al derecho español MIR PUIG, Santiago, "El delito", cit. nota n 15, p. 276; LORENZO SALGADO, "El delito", cit. nota n ${ }^{\circ}$ 17, p. 273. Asimismo, BUSTOS RAMÍREZ, Manual, cit. nota n 39, pp. 100 y 101, quien de hecho sostiene una definición sumamente amplia que lo lleva a ofrecer una relación de equivalencia con el tipo de amenazas; En similares términos, con cita de doctrina y jurisprudencia, MIRA BENAVENT, "El concepto", cit. nota n n $^{\circ}$ 10, pp. 96, 97, 133 a 138 y 151 y RAGUÉS I VALLES, Ramón, "Coacciones sin violencia. Apuntes sobre el difícil encaje de la legalidad en un sistema funcional del derecho penal", en MONTEALEGRE LYNETT, Eduardo (Coord.) Libro Homenaje al profesor Gunther Jakobs. El Funcionalismo en Derecho Penal, Bogotá (Colombia): Ediciones Universidad Externado de Colombia, Tomo II, 2003, p. 481 a 496, p. 485. Ragués también lo constata como fenómeno en España en términos que permiten sostener que en la práctica el delito es resultativo y no de medios vinculados, con ejemplos bastante evidentes (en p. 486 y 487). Como postura dominante en Alemania, en RAGUÉS I VALLES, “Coacciones", cit. nota n 60, p. 485 y en BASCUÑÁN RODRÍGUEZ, “La regulación”, cit. nota n², p. 297 y, en general, en BASCUÑÁN RODRÍGUEZ, "El Robo", cit. nota n4, p. 111. En el medio nacional -además de Matus y Ramírez- LABATUT GLENA, Derecho Penal, cit. nota no 23, p. 32. RAGUÉS I VALLES, "Coacciones", cit. nota $n^{\circ} 60$, p. 484 pone también de relieve que dicho desarrollo se motiva en la mayor trascendencia que adquiere la libertad de autodeterminación con el correr del tiempo, mientras que MIR PUIG, "El delito", cit. nota $\mathrm{n}^{\mathrm{o}} 15$, p. 274 lo vincula más bien a la ampliación de las posibilidades de actuación que ofrece la evolución de la humanidad. Sobre razones históricas próximas a dicha idea JAKOBS, "Coacciones", cit. nota n 13, p. 444. Dicho planteamiento, y la controversia implícita en él, presupone la conceptualización de ambas fórmulas delictivas como figuras de coerción y, por ello, como atentados contra la libertad. Los problemas que ofrece dicha interpretación se pueden reconducir a dos: El primero consiste en la necesidad de precisar qué casos de fuerza o violencia moral quedan incluidos en las amenazas condicionales (a riesgo de dejar dicha tipificación vacía de contenido) lo que no resulta sencillo. Pero, además -en segundo lugar- la enorme dificultad de que esta interpretación amplia o extensiva del término "violencia" resulte compatible con las exigencias del principio de legalidad. En este sentido ETCHEBERRY, Derecho Penal, cit. nota n ${ }^{\circ} 12$, T. III, p. 246 y en T.IV, p. 320, a partir de la advertencia de que se omite en este caso toda referencia a la idea de "intimidación". En el derecho comparado, contundente, RAGUÉS I VALLES, “Coacciones”, cit. nota n 60, pp. 492, 495 y 496. Muy claro, HRUSCHKA, Joachim, "La coacción en el sistema del derecho penal”, en, EL MISMO, "Imputación y Derecho Penal. Estudios sobre la teoría de la imputación” (edición a cargo de Pablo Sanchez-Ostiz), Navarra: Edit. Thomson-Aranzadi, 2005, pp. 257 a 288, p. 259. El resultado de la crítica lleva al resto de la doctrina a considerar que todo tipo de intimidación o fuerza moral debe circunscribirse al ámbito típico de las amenazas sosteniendo en paralelo que la disparidad penológica que ello supone es un grueso error del legislador que sólo puede corregirse a través de una reforma legal. En este sentido, BASCUÑÁN RODRÍGUEZ, "El Robo", cit. nota $\mathrm{n}^{\circ} 4$, p. 101; MAÑALICH R., Autotutela, cit. nota $\mathrm{n}^{\circ}$ 18, pp. 100 y 101; En el derecho español MIRA BENAVENT, "El concepto", cit. nota no 10, pp. 154 y 155.

${ }^{61}$ En este sentido el desarrollo histórico de las ideas tenidas en cuenta en el contexto de nuestra codificación, la posición geográfica y conceptual que ofrece la consagración positiva del régimen previsto para las amenazas claramente referidos al esquema francés y, en particular, belga- y las razones de mérito expuestas para la 
Polít. crim. Vol. 13, № 25 (Julio 2018) Art. 1, pp. 1-41.

[http://www.politicacriminal.cl/Vol_13/n_25/Vol13N25A1.pdf]

dicha opción se favorece por algunos de los caracteres precisos que ofrece la regulación de la hipótesis de amenaza condicional, en particular, tras la exclusiva consideración de la coerción moral en torno a la imposición de exigencias de carácter ilícito -así previsto en el texto original-; en la fijación del momento consumativo del delito en torno a la sola expresión de las amenazas condicionales (evidenciando con ello que las razones profundas de la incriminación ya se han satisfecho plenamente con dicho hito) y en la previsión de una regla de absorción que opera precisamente en aquellos casos en que se ha ejecutado el mal habiéndose cumplido la condición (como era en la regulación original), pues se trata de una radicación que pareciera restar toda relevancia a la coerción implícita ${ }^{62}$.

No obstante, varias de las consideraciones propuestas como respaldo de dicha tesis parecen inexactas o, cuando menos, no aportan el mérito que de ellas se reclama. Otras, como anticipamos, se basan en aspectos de la regulación positiva que han sido modificados. En este sentido destaca, en cuanto al desarrollo histórico, el que resulta altamente discutible que la calificación atribuida al modelo que ofrece la regulación del Código Penal español de 1848 -utilizado como base para las definiciones materiales propuestas a la hora de estructurar las amenazas- haya propuesto una estructura reconducible al modelo francés ${ }^{63}$. En cuanto al respaldo normativo de la propuesta no resulta posible estratificar las diversas hipótesis comisivas y su penalidad teniendo en cuenta en exclusiva el referente que aporta la gravedad del daño (del "mal"), sea que se utilice como referente el texto vigente o el original que ofrece nuestra regulación. De hecho, hay que tener en cuenta que la mayor incidencia a dichos efectos la ofrecen precisamente los casos en que se agregan contenidos asociados a la exigencia y cumplimiento de una condición, aspecto que en nada aporta en cuanto a la lesión de la seguridad individual ${ }^{64}$. Finalmente, y en cuanto al fondo, se debe considerar que

incriminación de los atentados a la seguridad individual parecieran correctamente reflejadas en la presentación del esquema de tipos penales que propone el tratamiento de las amenazas.

${ }^{62}$ Esta interpretación encuentra sustento en los comentaristas más clásicos. Tanto VERA, Robustiano, El Código Penal de la República de Chile comentado, Santiago: Imprenta de la P. Cador y cía., 1883, pp. 495 y 496, como FUENZALIDA, Alejandro, Concordancias y comentarios del Código Penal Chileno, Santiago: Imprenta Comercial, 1883, p. 316, identificaron en su tiempo el propósito delictivo en las amenazas (el dolo típico) con la concreción del mal y no con la pretensión de que se realice la exigencia o condición impuesta, teniendo precisamente en cuenta que la previsión legal de una regla de absorción para ese caso. Contrario a lo que se cree pareciera que el legislador original no propuso una distinción relevante en torno a la amenaza condicional en atención al cumplimiento o no cumplimiento de la mismo, sino que lo hizo en relación a la ejecución del "mal" delictivo que la configura. De ahí que la cláusula de absorción refiera el "propósito" del autor respecto al "hecho consumado", esto es, respecto al mal constitutivo de delito. Lo propio sugiere el tenor de la propuesta expuesta por Alejandro Reyes en la sesión n 63 de la comisión redactora en relación a la incorporación de la cláusula de subsidiariedad expresa en el $n^{\circ} 1$ del art. 269. Al respecto GUZMÁN DÁLBORA, El delito, cit. nota n², p. 67.

${ }^{63}$ Veremos más adelante que lo propio sucede tras el esquema que ofrece el modelo consagrado en el Código Penal español de 1850- siendo éstos, y no el de 1822 -adscrito sin lugar a dudas al "modelo francés"- el que se tuvo a la vista en el proceso de codificación. Lo relevante a este respecto es que se puede advertir un concreto cambio de eje o criterio rector en si se compara esta regulación con la que ofrece el Código Penal español de 1822 (marcadamente influenciado por el modelo francés). Para un desarrollo sintético véase LARRAURI, Libertad, cit. nota no 17, pp. 21 a 24 y BASCUÑÁN RODRÍGUEZ, "La protección”, cit. nota n², pp. 15 y 16. ${ }^{64}$ En concreto no parece discutible que en los modelos consagrados en los Códigos Penales españoles de 1848 y 1850 y en los respectivos comentarios -tenidos a la vista por la Comisión redactora- la pena se haya graduado conforme a la gravedad del "mal" que da contenido a la amenaza. No obstante, dicho criterio no explica la previsión de un tratamiento agravado para los casos de amenaza condicional que se incorpora en nuestro modelo 


\section{MALDONADO, Francisco. “Amenazas y coacciones en el Derecho Penal Chileno”.}

ninguno de los antecedentes ofrecidos permite dar cuenta de la premisa central que soporta la tesis, esto es, la estrecha vinculación que se sostiene entre la provocación de una afectación de la seguridad individual y de la libertad de autodeterminación o actuación a la vez, en términos que permitan afirmar que los atentados a la seguridad individual inciden siempre, en paralelo y en términos relevantes, sobre aquella. A nivel material basta tener en cuenta lo difícil que es advertir tras la amenaza simple algún tipo de incidencia que condicione las decisiones o actuaciones futuras del respectivo destinatario de las mismas y que puedan ser asociadas causalmente a la sola emisión de la advertencia futura de provocación de males ${ }^{65}$. Por su parte -y esto es lo más importante- también es posible constatar que el legislador asigna a nivel formal una valoración independiente a los actos que provocan una concreta incidencia sobre la libertad de autodeterminación, sea cuando toma la decisión de imponer una mayor sanción a las hipótesis de amenaza condicional (con independencia de la entidad del "mal"), cuando limita la punibilidad de la amenaza de males no constitutivos de delito a la hipótesis condicional y, evidentemente, cuando resuelve la consagración autónoma e independiente del tipo penal de coacción (al margen de su baja penalidad).

De esta forma, no pretendemos controvertir el hecho de que la regulación original de las amenazas se puede reconducir más fácilmente a la necesidad de tutela penal de la seguridad individual, ni que sea posible advertir signos concretos que avalan la idea de que la protección penal de dicho interés motivó una mayor atención y asignación de relevancia de parte del legislador de la codificación. No obstante, nada de ello permite explicar el resto de las definiciones propuestas en la regulación, en particular aquellas que evidencian en forma bastante nítida la asignación de un significado autónomo a la protección de la libertad de autodeterminación, constatación que resulta incompatible con la caracterización "compuesta" que propone esta aproximación. Ello impacta concretamente en la conceptualización que cabe asignar a la hipótesis de amenaza condicional teniendo en cuenta que el esquema que ofrece nuestro legislador se deja explicar en términos más precisos o certeros si se reconoce un rol independiente a cada uno de los referentes en juego -la seguridad y la libertad- a través de cada una de las diversas hipótesis previstas, tal como lo

local de forma que parece forzoso concluir que la comisión redactora abandonó ese criterio a la hora de estructurar la sistemática de las amenazas, máxime si tenemos en cuenta que dicha se trata de una diferenciación que resulta determinante en la estructura. En este sentido NOVOA MONREAL, "Cuestiones jurídicas", cit., nota $\mathrm{n}^{\mathbf{0}} 22$, p. 20.

${ }^{65} \mathrm{Si}$ bien parece efectivo que la provocación de condiciones materiales o referidas a la posición jurídica del individuo de carácter inestable pueden afectar su toma de decisiones en el futuro, se trata de una incidencia que carece por completo de la entidad o relevancia como para reclamar reconocimiento o mérito a los efectos de promover una intervención de carácter penal. Al respecto véase las reflexiones que propone CARRARA, Programa, cit. nota $\mathrm{n}^{\circ}$ 56, pp. 354 y 355 (Aptdo. 1575) pues a pesar de sostener una incidencia equivalente a la que objetamos la ajusta a su mérito propio en términos afines a lo recién señalado. BASCUÑÁN RODRÍGUEZ, "La regulación", cit. nota n², p. 289 señala al respecto: "Lo que hace que la formulación de la amenaza constituya un ataque a la liberta de decisión es precisamente su condicionalidad. Una amenaza simple no introduce motivos ajenos en la fase de deliberación de otra persona, porque al no existir la oferta simultánea de no irrogar el mal amenazado, al no precisarse un comportamiento como vía de escape a la amenaza, esta no puede influir en el proceso de deliberación del amenazado induciéndolo a adoptar una determinada decisión. Sin el elemento de la condicionalidad no puede hablarse de amenaza coercitiva, o sea, de atentado a la libre formación de la voluntad”. Así mismo ver p. 286, nota 220, donde advierte que la ejecución de otros delitos (como las lesiones) provocan una incidencia equivalente en la libertad de la víctima, sin que por ello ameriten ser conceptualizadas como agresiones de la libertad. 
Polít. crim. Vol. 13, No 25 (Julio 2018) Art. 1, pp. 1-41.

[http://www.politicacriminal.cl/Vol_13/n_25/Vol13N25A1.pdf]

hace -en términos generales- la doctrina dominante. Así, la amenaza simple se puede identificar como forma específica de afectación de la seguridad individual; la coacción como modalidad de atentado a la libertad individual y la amenaza condicional como un caso de carácter intermedio, tras el cual resulta posible advertir la afectación de ambos referentes sin que por ello se trate del mismo contenido o de contenidos indisolublemente unidos ${ }^{66}$.

En esta misma línea se pueden inscribir las opiniones de Alfredo Etcheberry pues junto con destacar el carácter pluriofensivo de la amenaza condicional radica su fundamento propio en torno a la necesidad de protección de la libertad de autodeterminación ${ }^{67}$. Si bien Etcheberry ofrece algunas interpretaciones que resultan más funcionales a la tesis contraria (por ejemplo, a la hora de conceptualizar el contenido que cabe atribuir a la seriedad y verosimilitud de la amenaza ${ }^{68}$ ) aporta concretas razones que permiten circunscribir sus respectivas afirmaciones en el sentido expuesto. Destaca entre ellas el que se aparta sensiblemente del esquema propuesto por el Código -que es el criterio que ocupa a través de todo el desarrollo de su obra general- relegando el tratamiento de las amenazas al grupo de los delitos "de peligro común" pero explicitando que las coacciones y las amenazas condicionales responden al amparo de la libertad ${ }^{69}$. Asimismo, el que a la hora de analizar el paralelo que se evidencia entre la coerción mediante violencia y la coerción mediante amenaza suscriba la crítica que subyace al análisis comparativo del grado de lesividad que se extrae de sus respectivos presupuestos típicos, concluyendo que en dichos casos resulta ilógico que "la lesión" (la coacción) tenga menos pena que "el peligro" (la amenaza ${ }^{70}$, denunciando en forma enfática la inconsistencia político criminal que ello supone ${ }^{71}$. Todas estas razones no hacen más que confirmar que en su concepción se trata de dos modalidades o formas de coerción paralelas, cuyo sentido incriminatorio radica en su incidencia (equivalente) sobre la libertad de autodeterminación.

\footnotetext{
${ }^{66}$ Estamos conscientes que dicha asunción obliga a asignar a uno de dichos objetos un rol preponderante pues el solo hecho de advertir el carácter pluriofensivo de la "amenaza condicional" no exime de la tarea de identificar cuál de ellas opera como criterio rector o medular (en tanto aparece como sistemáticamente dominante), en la medida que sólo de esa forma se puede desarrollar la dogmática propia que demanda su interpretación.

${ }^{67}$ En este sentido, ETCHEBERRY, Derecho Penal, cit. nota n ${ }^{\text {o }}$ 12, T. II, p. 319. Para Etcheberry también es claro que la coacción afecta a la libertad, y que la amenaza simple lesiona la seguridad. ETCHEBERRY, Derecho Penal, cit. nota $\mathrm{n}^{\circ}$ 12, T.III, p. 245. y T.IV, p. 320. En torno al derecho español, BUSTOS RAMÍREZ, Manual, cit. nota $\mathrm{n}^{\circ} 39$, p. 96 propone un tratamiento equivalente, si bien mantiene la idea de que la seguridad está vinculada a la libertad, como bienes jurídicos, en tanto presupuesto de actuación de la misma y que la regulación de las amenazas debiera distinguir nítidamente la figura condicional de la simple en atención al bien jurídico protegido.

${ }^{68}$ ETCHEBERRY, Derecho Penal, cit. nota n ${ }^{\circ}$ 12, T.IV, p. 320. Lo dicho aplica en particular a la comprensión de la exigencia de verosimilitud como equivalente a la afirmación de la posibilidad cierta de cumplimiento del mal con que se amenaza.

${ }^{69}$ ETCHEBERRY, Derecho Penal, cit. nota n ${ }^{\circ}$ 12, T. III, p. 245. Lo destaca, si bien con todo crítico, GUZMÁN DÁLBORA, El delito, cit. nota n², p. 107.

${ }^{70}$ ETCHEBERRY, Derecho Penal, cit. nota n ${ }^{\circ}$ 12, T. III, p. 245.

${ }^{71}$ Para Etcheberry, la ley penal chilena distingue claramente los conceptos de "violencia" e "intimidación", con lo cual toda "advertencia de males" queda necesariamente fuera de la expresión "violencia". La intimidación es por ello equivalente a la idea de amenaza -penalizándose bajo dicho título-, mientras que la violencia es solo el ejercicio de fuerza física directa, ofreciendo su tratamiento positivo una criticable desproporción. ETCHEBERRY, Derecho Penal, cit. nota n 12, T. III, pp. 245 y 246.
} 


\section{MALDONADO, Francisco. “Amenazas y coacciones en el Derecho Penal Chileno”.}

\subsection{La amenaza condicional como figura de coerción (atentado a la libertad)}

Más extrema -y explícita- es la opinión sostenida en nuestro medio local por Bascuñán Rodríguez $^{72}$. Lo primero a tener en cuenta es que dicho autor sostiene una interpretación diversa a la propuesta por Guzmán Dálbora en cuanto al sentido que cabe asignar a la amenaza condicional en el modelo español que sirve de base a nuestra codificación, demostrando, a partir del tratamiento histórico de la evolución de la codificación española, el que tanto en el Código Penal de 1848 como en el de 1850 se la concibe como una hipótesis de coerción $^{73}$. Sobre esa base concluye de forma directa que la regulación chilena adopta dicha estructura a nivel material, si bien lo hace bajo una forma externa que es la propia de la codificación belga ${ }^{74}$. Con ello le atribuye a la amenaza condicional un sentido histórico que la identifica como una modalidad específica de coerción, referida por ello a la protección de la libertad ${ }^{75}$.

Por sobre dicha constatación histórica Bascuñán recurre a la naturaleza que ofrece el nexo entre amenaza y condición en dichas hipótesis para arribar a una construcción de conjunto que lleva naturalmente a caracterizarlas como actos de constricción o coerción ${ }^{76}$, teniendo en cuenta que el uso o funcionalidad coercitiva del "mal" que el ejecutor advierte a la víctima aparece en dichos casos de manera evidente ${ }^{77}$. Cabe destacar a este respecto que nadie discute

\footnotetext{
${ }^{72} \mathrm{Al}$ respecto, con carácter general, véase BASCUÑÁN RODRÍGUEZ, "La protección", cit. nota n². Más sintético en BASCUÑÁN RODRÍGUEZ, "\&6. Delitos", cit. nota $n^{\circ} 19$. De manera más extensa, pero sin referencia al derecho local, en BASCUÑÁN RODRÍGUEZ, "La regulación", cit. nota n², pp. 191 a 306. Finalmente, a propósito de tratamientos más específicos, BASCUÑÁN RODRÍGUEZ, "El Robo", cit. nota nº, en particular, en pp. 97 y ss.

${ }^{73}$ Bascuñán entiende que los desarrollos conocidos suelen concentrarse exclusivamente en la regulación vigente sin indagar con la suficiente profundidad en su evolución histórica. De ahí que le parezca necesario ofrecer un estudio más acabado de dicho proceso. Al respecto BASCUÑÁN RODRÍGUEZ, "La regulación", cit. nota n², p. 196. Sobre el análisis propuesto véanse las pp. 267 a 280. En especial, con respecto al modelo instaurado en el Código Penal de 1848, en pp. 277 y ss. Para un análisis adicional diverso véase MIRA BENAVENT, "El concepto", cit. nota $\mathrm{n}^{\mathrm{O}} 10$, pp. 100 a 118.

${ }^{74}$ En ello coinciden plenamente con GUZMÁN DÁLBORA, José Luis, cit. nota no 2, pp. 64 y 65, quien señala: "La posición dentro del plan del Código y las mismas rúbricas no son, evidentemente, españolas, sino belgas; pero su substancia es netamente hispana". Asimismo, véanse pp. 244 y 245, más allá de la diversa interpretación del contenido sustantivo que ofrece el modelo español. De hecho, existe bastante claridad en doctrina en lo referido a entender que a la hora de tratar los delitos de amenazas la Comisión redactora se inclinó por seguir el esquema que proponía el Código penal belga. Así por ejemplo ETCHEBERRY, Derecho Penal, cit. nota $\mathrm{n}^{\circ} 12$, T. III, p. 197. Lo que Bascuñán sostiene es que dicha adhesión fue más bien formal, asociada a la estructura de tratamiento de las diversas infracciones, sin que reflejar por ello una influencia en cuanto al fondo de la regulación establecida. En el mismo sentido NOVOA MONREAL, "Cuestiones jurídicas", cit., nota $\mathrm{n}^{\circ} 22$, p. 20.

75 BASCUÑÁN RODRÍGUEZ, "La regulación”, cit. nota n², p. 288. Así también lo entendió NOVOA MONREAL, "Cuestiones jurídicas", cit., nota $\mathrm{n}^{\circ}$ 22, pp. 17, 18 y 19 (calificándolo como algo incuestionable). ${ }^{76}$ Nítido en BASCUÑÁN RODRÍGUEZ, "La regulación", cit. nota n², pp. 106 y 107.

77 BASCUÑÁN RODRÍGUEZ, "La regulación", cit. nota n², p. 288. En este mismo sentido NOVOA MONREAL, "Cuestiones jurídicas", cit., nota $\mathrm{n}^{\circ} 22$, p. 21, con referencia a autores que se manifiestan en un sentido equivalente y agregando concretamente que la vinculación de la amenaza a una determinada condición altera de forma inevitable el énfasis que pudiese ofrecer el acto de expresión que supone la formulación de la amenaza. El desarrollo de sustento se expone en pp. 17 a 21. Bascuñán (p. 289) destaca asimismo cómo la ausencia de nexo con una condición impide al mismo tiempo atribuirle carácter coercitivo, debiendo por ello
} 
Polít. crim. Vol. 13, № 25 (Julio 2018) Art. 1, pp. 1-41.

[http://www.politicacriminal.cl/Vol_13/n_25/Vol13N25A1.pdf]

-ni siquiera quienes identifican el objeto de protección en torno a alguna de las variantes de la seguridad individual- que la condición se orienta a la realización de una conducta activa o pasiva de parte del destinatario y no a un evento fortuito, dependiente de un tercero o del acaso $^{78}$. La condición constituye por ello una eventualidad que debe ser satisfecha por parte de la víctima bajo la presión que supone el llegar a padecer el contenido del mal que es objeto de advertencia, constituyendo un caso que evidencia claramente un supuesto de coerción. A dicho respecto se debe tener en cuenta que dicho carácter ("coercitivo") no aparece rechazado en la doctrina opuesta. Sus conclusiones son más bien consecuencia de la falta de relevancia o reconocimiento autónomo de la libertad de actuación y decisión a los efectos de su protección penal ${ }^{79}$.

Con ello Bascuñán sostiene -al igual que Etcheberry- que los casos de amenaza condicional debieran encontrarse regulados en forma paralela a la figura de coacción sin que esta última constituya por ello de una figura de carácter subsidiario. Su tratamiento debiera por ello ser del todo equivalente y, en cualquier caso, diverso al que cabe asignar a las amenazas simples que ofrecen una fisonomía y fundamentos distintos ${ }^{80}$. Sobre esa base sostiene que la notoria diferencia que presenta el tratamiento penológico de ambas modalidades de coerción arece por completo de justificación, constituyendo un grueso error del legislador que resulta imposible de remediar por vía interpretativa ${ }^{81}$. De esta forma, adscribe a la posición de quienes objetan el que sea posible o legítimo resolver esta contrariedad -prácticamente indiscutible- mediante la relajación de los términos bajo los cuales se describe la "violencia" como medio comisivo en las coacciones ${ }^{82}$, inclinándose en favor de una reestructuración que necesariamente requiere una reforma de derecho positivo ${ }^{83}$.

Por sobre dicho déficit la conceptualización expuesta pareciera recibir respaldo en la normativa chilena vigente. Primero, pues la amplitud de males que se consideran idóneos

orientándose por un sentido diverso. Finalmente, se debe tener presente que se trata de una cuestión que atañe a la naturaleza propia de los casos que se pretenden regular, los que ofrecen características propias al margen de las valoraciones y énfasis que les asigna cada sistema jurídico. De ahí que la persistencia en la mantención de un tratamiento diversificado de la amenaza condicional y la coerción, con sus correspondientes diferencias sistemáticas (momento consumativo, medios comisivos, sanciones, etc.) es una fuente inagotable de dificultades. En este sentido BASCUÑÁN RODRÍGUEZ, “La regulación”, cit. nota n², p. 306.

${ }^{78}$ Al respecto véase BASCUÑÁN RODRÍGUEZ, "La regulación”, cit. nota n², p. 288.

${ }^{79}$ Se refleja con claridad en la crítica que al respecto expone Guzmán Dálbora, en cuanto sostiene que la advertencia de un paralelo entre la amenaza condicional y la coacción constituye "algo que la ley no dice", teniendo en cuenta la regulación conjunta de todas las amenazas y la ausencia de un tipo específico de coerción. GUZMÁN DÁLBORA, El delito, cit. nota n², p. 328 y 329.

${ }^{80}$ BASCUÑÁN RODRÍGUEZ, “La protección”, cit. nota $\mathrm{n}^{\circ} 2$, p 12; y en, del mismo, cit. nota nº19, p. 2. Se desprende asimismo del tratamiento que ofrece en, BASCUÑÁN RODRÍGUEZ, "La regulación”, cit. nota n², pp. 280 y ss., especialmente en p. 285. En el mismo sentido BUSTOS RAMÍREZ, Manual, cit. nota n 39, pp. 96 (sugiriendo que solo debiesen quedar como "amenazas" las no condicionales), 97 y 100.

${ }^{81}$ BASCUÑÁN RODRÍGUEZ, "El Robo", cit. nota nº 4, p. 101, calificándolo incluso como un "absurdo".

${ }^{82}$ Sobre ello véase Supra nota 60.

${ }^{83}$ Expresamente, BASCUÑÁN RODRÍGUEZ, "El Robo", cit. nota nº4, p. 102. En el mismo sentido, por razones del todo análogas, MAÑALICH R., Autotutela, cit. nota nº 18, pp. 100 a 101. Esencialmente este autor coincide con Bascuñán en que el núcleo de la conducta típica de las amenazas condicionales radica precisamente en la condición, sin que sea posible en modo alguno llegar a vincular la amenaza simple a la afectación de la libertad de autodeterminación. 


\section{MALDONADO, Francisco. “Amenazas y coacciones en el Derecho Penal Chileno”.}

para llegar a configurar una amenaza condicional incluye desde siempre aquellos que carecen de relevancia penal a diferencia a como sucede con la amenaza simple. Segundo, pues la propia graduación de las penas aplicables al delito de amenazas lleva a concluir que el legislador le asigna mayor relevancia al contenido que ofrece la constricción de la libertad que opera en la modalidad sujeta a condición, si se lo compara con la incidencia que a dichos efectos tiene el contenido objetivo o gravoso del "mal" que le sirve de objeto, debiendo por ello descartar la idea de que este último opera como criterio rector a dichos efectos ${ }^{84}$. Dichos contenidos se complementan además en el mismo sentido a través de buena parte de las modificaciones que la ley 19.659 introdujo en el derecho positivo chileno en el año 1999. Y no sólo por la estrecha vinculación que presentan los objetivos que inspiran dicha reforma con el tratamiento de penal que cabe asignar a la coerción o constricción de la libertad, en tanto dirigida a resolver los problemas prácticos que a la época presentaban los casos de coerción y extorsión que se ejecutan en el contexto de la cobranza de deudas de carácter extrajudicial. En concreto, se suprime la exigencia de ilicitud de la condición impuesta en las amenazas condicionales siendo reemplazada por la exigencia de un "nexo ilícito" que permita vincular su imposición con el mal que le sirve de objeto, con lo cual el fundamento de la figura no puede sino radicar en la concreta constricción (ilegítima) de la libertad que ello supone $^{85}$. Lo propio sucede con la supresión de la cláusula de absorción de la amenaza condicional en tanto favorece una solución concursal para el evento en que se lleva a cabo el mal advertido -sea que se haya cumplido o no con las condiciones impuestas-, lo que solo se explica por el hecho de que el contenido que es objeto de "absorción" no alcanza, ni puede alcanzar, a la afectación de la libertad de autodeterminación dando lugar al concurso ${ }^{86}$. Lo

${ }^{84}$ Véase BASCUÑÁN RODRÍGUEZ, “El Robo”, cit. nota n4, p. 97.

${ }^{85} \mathrm{La}$ seguridad individual (referida a la posición jurídica del individuo "jurídica”) no puede verse afectada mediante la ejecución de males lícitos y menos aún por la sola advertencia de su ocurrencia futura. Así se explica la referencia original del texto positivo chileno a la exigencia de una condición ilícita (al respecto véase GUZMÁN DÁLBORA, El delito, cit. nota n², pp. 387 y ss.) y el que la supresión de esta exigencia obligue, casi naturalmente, a radicar la eventual ilicitud penal de estos casos en torno a las situaciones en que dicha advertencia adopta la forma de una coerción "ilegítima". Sobre la existencia de este problema FERNÁNDEZ DIAZ, “Amenaza”, cit. nota $\mathrm{n}^{\circ} 34$, pp. 188 y ss. y, en especial, en p. 189, nota n 15 (más allá de insinuar que no es necesario recurrir a ningún criterio). Cabe señalar que la precisión del criterio para determinar en qué casos ello ocurre no es tarea sencilla. Sobre los criterios propuestos para configurar esta delimitación, véase JAREÑO LEAL, Las amenazas, cit. nota n 17, pp. 58 y ss.; JAKOBS, “Coacciones”, cit. nota n 13, pp. 463 y ss. A dichos efectos, la doctrina dominante suele manifestarse a favor de la desconexión de medio a fin, entre la condición y la amenaza, como propuesta de solución. En este sentido el propio BASCUÑÁN RODRÍGUEZ, "La regulación", cit. nota ${ }^{\circ} 2$, p. 287, reconociendo que se trata de una cuestión sujeta a debate. En el mismo sentido GUZMÁN DÁLBORA, El delito, cit. nota n², p. 295, 375 destaca que constituye el criterio dominante en España desde Rodriguez Devesa. Asimismo, BUSTOS RAMÍREZ, Manual, cit. nota no 39, p. 113. En Chile Novoa Monreal procuró en su tiempo trata el tema asociado a la precisión de lo que debe entenderse por "mal". Si bien se limita a constatar que se considera como tal cuando está formulado en términos conminatorios (vinculado al forzamiento de la voluntad de otro), sin advertir que el problema es aún más complejo. Al respecto NOVOA MONREAL, “Cuestiones jurídicas”, cit., nota no 22, p. 22.

${ }^{86}$ Esta interpretación cuenta además con pleno reconocimiento en la historia de la ley: p. 67. “Al mismo tiempo, se suprime al final del número la oración "a no ser que merezca mayor pena el hecho consumado, caso en el cual se impondrá ésta." Ello, porque esta regla de absorción del delito de amenaza por la punición del "hecho consumado" sólo puede tener algún sentido tratándose de la amenaza simple, a que se refiere el numerando tercero del mismo artículo. En el caso de la amenaza condicional, la lesión a la libertad personal que se concreta en la imposición de una condición bajo amenaza, no es consumida por la efectiva irrogación del mal conminado, ya que una amenaza defectuosa no absorbe el intento de coacción". (El destacado es nuestro) 
Polít. crim. Vol. 13, № 25 (Julio 2018) Art. 1, pp. 1-41.

[http://www.politicacriminal.cl/Vol_13/n_25/Vol13N25A1.pdf]

dicho se ratifica aún más por la exclusiva consideración de dicha cláusula en torno al supuesto propio de la amenaza simple y por la extensión de la sanción de la amenaza de males no delictivos respecto a todo evento que la asocie a una condición (y no solo a los supuestos en la que la condición se cumple, como proponía nuestro tex to positivo original ${ }^{87}$, clarificando con ello que lo relevante en dichos casos no radica en el mal sino en su exclusiva asociación con una determinada condición ${ }^{88}$.

Lo dicho permite atribuir más peso las razones que apoyan la idea de que la amenaza condicional presenta una naturaleza completamente diversa a la que es propia de la amenaza simple, constituyendo concretamente una forma o modalidad de coerción que se ubica en un lugar paralelo al que se asigna a la coacción y cuyos fundamentos se orientan a favor de la protección de la libertad de autodeterminación individual. Esta es por lo demás la tesis que en la actualidad concita un mayor grado de adherencia en las diversas opiniones constatables en el derecho comparado, lo que a nuestro juicio se explica por la consolidación que ha ido experimentando la idea de que la libertad de autodeterminación individual constituye un interés autónomo que es digno de reconocimiento y protección jurídica ${ }^{89}$.

No obstante, no es posible asumir que lo dicho agote el tratamiento que supone dicha conceptualización. Queda aún pendiente la resolución de aquellos aspectos problemáticos que ofrece el contenido de la regulación positiva y cuya solución no se favorece al adoptar dicha opción. A ello nos dedicaremos en el apartado siguiente para finalizar.

\section{Problemas específicos de la conceptualización de la amenaza condicional como modalidad de coerción. A modo de hipótesis.}

En primer lugar, debemos tener en cuenta que resulta indiscutible que el legislador regula en forma conjunta y bajo una misma sistemática la totalidad de hipótesis de amenazas punibles, aportando un contexto que pareciera poco favorable a una conceptualización separada de su núcleo fundamental. Es más, dicha sistemática o estructura tampoco resulta modificada por la reforma introducida por la Ley 19.659, a pesar de su indiscutible orientación y teniendo en

\footnotetext{
${ }^{87} \mathrm{Al}$ respecto véase lo señalado en la historia de la ley, en p. 68. En este mismo sentido NOVOA MONREAL, "Cuestiones jurídicas", cit., nota $\mathrm{n}^{\circ} 22$, p. 18, quien destaca que si el contenido de injusto de la amenaza se extrajera del que detenta el mal que se advierte, esta cláusula no tendría explicación alguna.

${ }^{88}$ Historia de la ley, en p.68: “El último número del artículo 2o que se propone reemplaza el artículo 297 -que sanciona con la pena de reclusión menor en cualquiera de sus grados las amenazas de un mal que no constituya delito hechas en la forma expresada en el número $1^{\circ}$ del artículo 296-, con dos finalidades. En primer lugar, para considerar también aquellas amenazas que se efectúan bajo condición y el culpable no hubiere conseguido su propósito - contempladas en el No 2 del artículo 296-, con lo cual no se dejan impunes los casos en que se formula la amenaza y la condición, pero el coaccionado efectúa la denuncia en vez de acceder a las exigencias del coaccionador, y en segundo término, para reducir el marco penal a reclusión menor en sus grados mínimo a medio, lo que resulta congruente con la conducta tipificada, que no justifica una sanción tan grave, equivalente a la de los abusos sexuales, sobre todo si, a partir de esta reforma, será inequívocamente punible aún el caso de amenaza con condición no cumplida". Lo destaca asimismo FERNÁNDEZ DIAZ, "Amenaza", cit. nota n³4, p. 189 , nota $\mathrm{n}^{\circ} 15$.

${ }^{89}$ Al respecto ETCHEBERRY, Derecho Penal, cit. nota $n^{\circ}$ 12, T. III, p. 195. Asimismo, BASCUÑÁN RODRÍGUEZ, "El Robo", cit. nota n4, p. 106.
} 


\section{MALDONADO, Francisco. “Amenazas y coacciones en el Derecho Penal Chileno”.}

cuenta que la adscripción en sentido fuerte a la tesis propuesta debiese reclamar una concreta reformulación que, cuando menos, aborde conjuntamente la regulación de ambas formas de coerción, iguale el tratamiento punitivo dispuesto y se haga cargo por separado de la hipótesis que propone la amenaza simple. Esta última decisión, además, pasa por revisar si el contenido de desvalor que soporta este último delito puede hoy en día reclamar la amplitud y entidad que le concedió el legislador originario, considerando especialmente los problemas que ofrece la precisión de su contenido de injusto al margen de la sanción de una "tentativa anticipada" o "alejada"

No obstante, $-\mathrm{y}$ descartando de plano que la identidad o similitud del medio comisivo pueda tener a este respecto alguna relevancia ${ }^{91}$ - creemos que las razones materiales expuestas son superiores a las estrictamente formales, existiendo varios ejemplos históricos en el derecho chileno que son reflejo de condiciones similares. De esta forma parece suficiente con recurrir a una explicación histórica sobre el contexto de su establecimiento original para justificar dicha estructura o presentación sistemática -formal- sin que dicho dato constituya a nuestro juicio ningún obstáculo para asumir una adecuada interpretación sustantiva de las figuras en cuestión (más allá de los evidentes efectos "distractores" que provoca su tratamiento conjunto $)^{92}$. A dicho respecto la mayor dificultad pareciera asociada a la consideración de elementos comunes cuyo contenido reclamaría una diversa configuración si se postula

\footnotetext{
${ }^{90} \mathrm{Si}$ bien no es este el lugar para abordar dicha problemática - pues excedería los objetivos propuestos en la medida en que no incide en la estructura sistemática- resulta necesario dar cuenta de ciertos aspectos relevantes de tener en cuenta. Existe consenso en asumir que originalmente las amenazas fueron reconocidas como verdaderos actos preparatorios punibles, recibiendo una regulación inicial acotada a delitos de especial gravedad y junto a su tipificación en particular (en cada caso) en el modelo original francés. Al respecto, sintética, LARRAURI, Libertad, cit. nota $\mathrm{n}^{\circ} 17$, p. 23. Los problemas se vinculan concretamente al déficit de lesividad que ello propone, los que se extreman cuando se resuelve regularla como figura general. Sobre las discusiones que se suscitaron en el modelo español previo al Código de 1848 véase GUZMÁN DÁLBORA, El delito, cit. nota $n^{\circ} 2$, p. 477 y que decantan en la necesidad de identificar un referente de protección diverso. Este es el origen de las referencias a la seguridad y en particular, a la seguridad individual. No obstante, la regulación mantiene elementos que solo reciben explicación bajo la conceptualización de la amenaza simple como "tentativa anticipada": Por un lado, hay que tener en cuenta que hasta bien entrado el siglo XX la sanción de la amenaza simple en España dependió de la gravedad del delito que es objeto de la misma, en una evidente muestra de que su desvalor se lo identifica con el que aporta dicho delito. Al respecto, GUZMÁN DÁLBORA, El delito, cit. nota $\mathrm{n}^{\circ} 2$, p. 304. Por otro lado, la regla de absorción - prevista en nuestro caso de forma expresano se explica si la lesión que se produce se vincula a la "seguridad individual", pues dicha afectación se puede constatar al margen de la que aporte la eventual concreción futura del mal delictivo.

${ }^{91}$ Hay que tener en cuenta que la modalidad comisiva sea idéntica en ambos delitos no es algo distintivo o definitorio de su respectivo núcleo esencial, en tanto se vincula a la forma de ataque y no al contenido de la afectación. Esto último no tiene por ello relevancia para la determinación de la naturaleza de las respectivas figuras delictivas más allá de que incida en la generación de una imagen que en apariencia favorece una asimilación. En este sentido violación y robo detentan una naturaleza completamente diversa a pesar de que el modo comisivo en ambas hipótesis se define -simplificando los términos- a partir de "fuerza o intimidación". Lo propio sucede en la fórmula tradicional de estupro por engaño y la estafa, a pesar de la identidad del medio comisivo.

${ }^{92}$ Sobre bases similares BASCUÑÁN RODRÍGUEZ, "La regulación”, cit. nota n², p. 285 sostiene que dicho tratamiento conjunto debe ser interpretado, a lo sumo, como una cuestión de economía legislativa.
} 
Polít. crim. Vol. 13, № 25 (Julio 2018) Art. 1, pp. 1-41.

\section{[http://www.politicacriminal.cl/Vol_13/n_25/Vol13N25A1.pdf]}

efectivamente una diferenciación, destacando concretamente la conceptualización del dolo y de la seriedad y verosimilitud de las respectivas amenazas ${ }^{93}$.

En segundo lugar -y acá está lo más importante- se debe resolver el problema que supone la fijación del momento consumativo que determina la punibilidad de la amenaza condicional ${ }^{94}$, cuestión que a nuestro juicio se encuentra estrechamente vinculada a la resolución del absurdo que supone su mayor penalización en comparación con el régimen previsto para la coerción violenta. A este respecto creemos que la sola constatación del error y desproporción que ello supone no puede limitarse a un reclamo de lege ferenda-como hace Etcheberry, Bascuñán o Mañalich- más allá de que es evidente que ofrece un contexto tremendamente complejo para sostener una interpretación plausible $e^{95}$.

Tomando como punto de partida que el modo comisivo de la coerción (violenta o no violenta) no es algo que determine una diferencia esencial -pues en cualquier caso se puede advertir una afectación de la libertad que resulta del todo equivalente ${ }^{96}$ - y que, de lege ferenda, resulta deseable una regulación conjunta y homogénea para la amenaza condicional y para la coerción violenta ${ }^{97}$, hay dos elementos de juicio adicionales que resulta necesario tener en cuenta en forma particular, pues aportan matices respecto a dicha igualdad de base u original. Por un lado, no se puede obviar que legislaciones como la nuestra consideran y mantienen una sanción autónoma para el acto de "amenaza simple", de forma que es indiscutible que el

\footnotetext{
${ }^{93}$ Véase lo dicho supra en el apartado 2 sobre el diverso contenido que cabe asignar a dichos elementos según cuál fuese el referente de protección al que se asocian.

${ }^{94}$ Bascuñán destaca que una de las diferencias oscuras entre coacciones y amenazas es el diverso momento consumativo. Sobre dicha problemática BASCUÑÁN RODRÍGUEZ, "La regulación", cit. nota n², pp. 289 y ss. No obstante, véase lo dicho sobre sus opiniones supra en nota 35.

${ }^{95}$ Sobre ello véase JASO ROLDÁN, "Capítulo XXX", cit. nota nº17, p. 303.

${ }^{96}$ Las diferencias son prácticamente "morfológicas" -provienen de los caracteres naturales que presenta cada forma de ataque, como indica SOTO PIÑEIRO, "Nota y comentario", cit. nota $n^{\circ} 18$, p. 123- y no ofrecen contenidos valorativos o esenciales relevantes, teniendo en cuenta que en ambos casos se afecta en forma equivalente la capacidad de libre decisión del individuo. Por todos, BUSTOS RAMÍREZ, Manual, cit. nota no 39, p. 100. Este último autor critica la tendencia a advertir diferencias esenciales con base en una distorsión de la clásica distinción propuesta por Binding en torno a la capacidad genérica de obrar; el proceso motivacional que precede a la actuación y la ejecución de las decisiones o capacidad de actuación (sobre ello véase JASO ROLDÁN, "Capítulo XXX”, cit. nota n¹7, p. 298). En particular, en la comprensión de cada categoría como auténticos bienes jurídicos diferentes o como "momentos distintos" de la lesión (sintéticamente, origen, riesgo y lesión). En relación a esto último (véase, BASCUÑÁN RODRÍGUEZ, "La regulación", cit. nota n², p. 282) hay que tener en cuenta que se identifica a la amenaza con una interferencia en el proceso motivacional que precede a la actuación y a la violencia como una interferencia en la actuación libre del individuo (frente a una decisión y adoptada). Esta tesis no solo no resuelve el problema de la desproporción penológica - de hecho, lo agrava pues sugiere que los diversos momentos de la lesión deben tener una sanción diversa- sino que, en opinión de BASCUÑÁN RODRÍGUEZ, "La regulación”, cit. nota n², p. 294 -acertada a nuestro juicio- obvia el que la incidencia de cualquier conducta sobre la motivación del individuo presupone su habilitación para decidir y para luego actuar o ejecutarla, pues de otra forma se torna irrelevante la idoneidad coercitiva de la incidencia en la motivación. Con más detalle en BASCUÑÁN RODRÍGUEZ, "La regulación", cit. nota n², pp. 289 y ss. Al respecto Bascuñán, destaca cómo dicha categorización -complementada- aporta para la delimitación de ambos modos comisivos Sobre ello véase infra nota 142.

${ }^{97}$ En este mismo sentido, BASCUÑÁN RODRÍGUEZ, "La regulación”, cit. nota n², pp. 302 y 304. Dicha regulación presenta además la ventaja de reducir el campo de las relaciones problemáticas entre intimidación y amenaza condicional.
} 
MALDONADO, Francisco. "Amenazas y coacciones en el Derecho Penal Chileno”.

legislador expresa un grado de consideración particular (negativa) respecto del supuesto que la configura, a partir de la afirmación de una lesión de la seguridad individual. Lo relevante es que dicho desvalor solo pareciera concurrir en una parte de los casos de "coerción mediante amenaza" -aquellos en que la realización potencial del mal se difiere para un contexto diverso de aquél en que es advertido- sin que, por lo demás, sea posible advertirlo en los casos de coerción física directa. Por otro lado, tampoco se puede obviar que las legislaciones mantienen en la actualidad algún grado de reconocimiento a ciertas expresiones reconducibles históricamente al llamado "crimen vis", asociado estrechamente -desde el derecho romano- al desarrollo de un comportamiento físicamente agresivo que recae en el cuerpo de otra persona.

A dicho respecto se debe tener en cuenta que ambas definiciones encuentran reflejo en nuestro derecho positivo, haciendo factible reconocer tras el "acto de amenaza" y tras el ejercicio de violencia (física) determinados significados particulares que se agregan al que ofrece su contenido o carácter de base como actos coercitivos ${ }^{98}$. En este sentido, no resulta discutible que el legislador penal chileno considera que la seguridad individual constituye un interés digno de protección penal y que la conducta consistente en la sola "advertencia de un mal futuro dependiente de la mera voluntad del emisor" la puede llegar a afectar, asignándole mérito para ser proscrita bajo amenaza de pena. Dicha definición se estructura al margen y con total independencia de su eventual carácter coercitivo, esto es, de la conexión que pueda vincular su ejecución con la imposición de una determinada condición o forma de actuación que dependa de la voluntad del destinatario (o "victima" si se prefiere). Si bien se trata de una definición legislativa discutible en su mérito -fundamentalmente por cuanto se trata de comportamientos que avanzan poco o casi nada respecto a la mera exteriorización de las intenciones ${ }^{99}$ - constituye un dato que el intérprete no puede desconocer, ni menos obviar, mientras conserve vigencia en el derecho positivo. Con ello, resulta forzoso reconocer que el acto de proferir una amenaza aporta un contenido de injusto -una razón de "merecimiento" de pena- en todas las hipótesis en que concurra -por insuficientes que nos parezcan las razones del legislador-, sea cuando se trate de un acto que limita sus objetivos a la sola expresión de una resolución delictiva a ser ejecutada en el futuro o cuando se encuentre

\footnotetext{
${ }^{98}$ Una opinión diversa se puede advertir en Bascuñán, quien interpreta -coherentemente, conforme a sus premisas- que la pena de la amenaza condicional evidencia un determinado desvalor asociado a la afectación de la libertad de autodeterminación en cuanto tal y no en referencia a la afectación de la seguridad. Al respecto véase BASCUÑÁN RODRÍGUEZ, "El Robo", cit. nota n4, p. 106.

${ }^{99} \mathrm{Si}$ bien esta advertencia o inquietud pretende ser resuelta precisamente a partir de las exigencias de complemento de su realización (en particular, mediante la exigencia de seriedad asociada a la constatación de un ánimo serio o real de llevarlas a cabo) nadie puede discutir que se trata de conductas próximas a la mera exteriorización de una disposición de voluntad, siendo altamente discutible llegar a advertir tras su ejecución un riesgo cierto de afectación concreto. Al respecto véase CARRARA, Programa, cit. nota $\mathrm{n}^{\circ}$ 56, p. 330. (\& 1560). En Chile NOVOA MONREAL, "Cuestiones jurídicas", cit., nota $\mathrm{n}^{\circ} 22$, p. 15 para quien en las amenazas se sanciona a primera vista la mera exteriorización de intenciones o, en particular, de la voluntad criminal, que identifica con las primeras fases del iter críminis, incluso antes que los actos de carácter preparatorio (p.16). Al respecto deben tenerse en cuenta las acotaciones expuestas por el comisionado Fabres en la sesión 63 de 20 de octubre de 1871 de la Comisión redactora del Código Penal y que dan cuenta de que en la discusión de las amenazas se tuvo presente la necesidad de suplir los déficits de lesividad asociados a la posición y distancia que dichas conductas presentan respecto de la lesión. Se concluye por ello que debían excluirse todo tipo de manifestaciones orientadas a fines que no sean expresión real del propósito de llevarlas a cabo o de influir temor. Al respecto GUZMÁN DÁLBORA, El delito, cit. nota n², p. 67.
} 
Polít. crim. Vol. 13, No 25 (Julio 2018) Art. 1, pp. 1-41.

[http://www.politicacriminal.cl/Vol_13/n_25/Vol13N25A1.pdf]

funcionalmente orientada a materializar un acto de constricción ${ }^{100}$. De ahí que, en este último supuesto, proponga la consideración de un plus de injusto sobre el que se reconoce a la constricción de la libertad.

Se podría sostener que en los casos de coerción ello no sucede, pues sería más bien la "amenaza", entendida en su sentido propio o autónomo, la que termina por desnaturalizarse. La incertidumbre que supone el no saber si el mal llegará a concretarse -y que opera como de supuesto de la inseguridad que provoca- se ve sensiblemente afectada por el hecho de que dicha eventualidad ya no depende de la sola voluntad y decisión del emisor. Su imposición "condicionada" coloca al destinatario, por definición, en una posición determinante a dicho respecto, en términos que permiten sostener incluso que comparte el destino de su suerte (al menos en parte ${ }^{101}$. Lo dicho se demostraría en el hecho de que la constricción de la voluntad que suponen estos casos requiere precisamente en dicha "potencialidad" en la víctima (de control de la ocurrencia o evitación del mal) pues de no existir opciones de que ésta cumpla "voluntariamente" lo requerido, el tormento o amenaza carecerá de toda fuerza coercitiva ${ }^{102}$.

No obstante, creemos que dicha aproximación pasa por alto que la provocación de un efecto coercitivo en estos casos requiere precisamente de las consecuencias lesivas que son reconocidas a la amenaza para ser tal. En particular, la efectiva provocación de un estado de inseguridad -más o menos general- en el destinatario ${ }^{103}$, pues solo en dicho caso constituirá una expresión apta o idónea para llegar a incidir de manera efectiva en su voluntad. De no ser así, habría que concluir que las expresiones proferidas no constituyen un motivo real (una razón de mérito) o una interferencia relevante, afectando con ello su idoneidad como medio coercitivo (expresado concretamente en las exigencias de seriedad o verosimilitud). Lo característico de dicha "afectación" radica por ello en la "incertidumbre" de la ocurrencia del mal, característica que -por lo dicho- estimamos concurrente en condiciones semejantes -o cuando menos equivalentes- en la amenaza conminatoria.

Esta acotación presenta una relevancia adicional, pues permite advertir que no es posible identificar o reconocer los efectos que dan forma al injusto propio de las amenazas si la eventualidad asociada al riesgo de concreción del mal que le da contenido no presenta algún grado de independencia o desconexión respecto al momento o instancia en que ésta es proferida, cuestión que anunciamos tangencialmente algunas líneas más atrás. De no ser así el carácter "incierto" de la eventualidad del mal se vería sensiblemente disminuido, afectando con ello -de forma determinante- su potencialidad lesiva respecto de las condiciones de seguridad de la víctima. Ello pues una vez que se ha agotado del contexto en que es proferida

\footnotetext{
${ }^{100}$ En este mismo sentido MIR PUIG, "El delito", cit. nota $n^{\circ} 15$, p. 283. Lo reconoce también LORENZO SALGADO, "El delito", cit. nota n 17, pp. 283 y 284.

${ }^{101}$ En este sentido BASCUÑÁN RODRÍGUEZ, "La regulación”, cit. nota n², p. 286.

${ }^{102}$ Lo dicho no obsta a reconocer que la potencialidad y "sensación” de control de la víctima es siempre relativa, en tanto quien profiere la amenaza puede perfectamente incumplir su parte de la condición (ejecutar igualmente el daño o mal previamente anunciado a pesar de que la víctima ha dado cumplimiento a lo requerido). Esta potencialidad -o eventualidad- no obsta sin embargo a la relativización planteada pues dicho "riesgo" parece menor si se tiene en cuenta que el propio autor de la amenaza ha optado por "suspender" o "supeditar" dicha advertencia a favor de una determinada constricción, aportando con ello un elemento de juicio que evidencia que sus objetivos no se orientan a favor de la materialización de dicho daño.

${ }^{103} \mathrm{Al}$ respecto, en general, GUZMÁN DÁLBORA, El delito, cit. nota nº2, pp. 180 y ss.
} 
MALDONADO, Francisco. “Amenazas y coacciones en el Derecho Penal Chileno”.

la amenaza, en dichos supuestos culmina también la posibilidad de materialización del correspondiente riesgo, pudiendo alternativamente haberse "transformado" (concretizado) en una "lesión" (cuya relevancia a efectos penales se determina de forma independiente). Así por ejemplo el padre que se encuentra separado de hecho de su mujer, que llega ebrio al hogar en busca de sus hijos cuando le corresponde una visita y que amenaza a su ex mujer con golpearla si no se los entrega en el acto, incurrirá en maltrato o lesiones punibles si concreta dicha advertencia siendo inocuo su comportamiento si no la cumple y se retira del lugar, todo ello bajo el supuesto de que la mujer no cede a la presión y al margen de la relevancia que tiene el hecho como acto de constricción. Por ello no resulta posible reconocer o identificar tras dicho supuesto una auténtica "amenaza" punible en cuanto tal (esto es, una afectación a concreta a la seguridad individual) si la advertencia que su ejecución conlleva (respecto a la provocación de un "mal") no se emite con una perspectiva de futuro ${ }^{104}$, pues la ausencia de dicha característica modifica por completo el mérito que dicho supuesto ofrece para estructurar autónomamente una incriminación penal. En este sentido, si al acto de advertencia de un mal le sucede en forma inmediata su propia concreción, corresponderá la valoración del correspondiente daño provocado (punible) mientras que en los demás casos -esto es, a falta de un efecto lesivo de carácter actual- dicho hito constituirá un acto del todo "inofensivo" desde la perspectiva del mérito que ofrece para la seguridad (futura) de la víctima ${ }^{105}$, pues no será posible advertir un riesgo para los intereses del destinatario que se encuentre "pendiente de ejecución"106. Por ello la lesión de la seguridad requiere que el daño anunciado admita ser proyectado como un evento de futuro.

Con ello la hipótesis consistente en la advertencia de un mal cuya ejecución se dispone para un contexto inminente solo puede llegar a ser desvalorada en cuanto acto de constricción, esto es, cuando se encuentra asociada a la satisfacción o cumplimiento de una concreta condición, supuesto que el legislador pareciera tratar de manera diferenciada tras el uso

\footnotetext{
${ }^{104}$ En el mismo sentido GUZMÁN DÁLBORA, El delito, cit. nota n², pp. 318 y 319.

${ }^{105}$ A dichos efectos tomamos como base la premisa de todo acontecimiento que es sometido a valoración, en cuanto potencial conducta típica, debe ser apreciado en su conjunto. Bajo dicha óptica la advertencia de la amenaza de males constitutivos de delito que se concreta en el propio contexto en que es proferida no es sino parte del iter o desarrollo ejecutivo del mismo delito, constituyendo un acto anterior copenado. Este mismo razonamiento lleva a desechar su punibilidad si dicho delito no se llega a ejecutar -no llega a "principiar"- pues en dicho caso la ejecución quedaría en el estadio propio de la mera exteriorización de la voluntad (regido, si se concede el punto, por la lógica de la consunción inversa). El que no se aprecie con claridad en una primera impresión es fruto a nuestro juicio de la tradicional forma de entender al delito como "acción física" o "movimiento perceptible" que se encuentra a todas luces superada.

${ }^{106}$ Con claridad CARRARA, Programa, cit. nota $n^{\circ}$ 56, p. 359, \& 1577. Concretamente, identifica un déficit en la seriedad y en la verosimilitud que incide negativamente en la posibilidad de asignarle mérito a efectos de punición. Sobre ello véase LARRAURI, Libertad, cit. nota ${ }^{\circ}$ 17, p. 253.
} 
Polít. crim. Vol. 13, № 25 (Julio 2018) Art. 1, pp. 1-41.

[http://www.politicacriminal.cl/Vol_13/n_25/Vol13N25A1.pdf]

"nominal" de la expresión "intimidación"107 y que se ubica en un lugar paralelo respecto al que ocupa la coerción violenta ${ }^{108}$.

De esta forma, creemos que la tradicional fórmula que distingue el tratamiento que cabe dispensar a la advertencia de un mal coactivo de carácter inmediato respecto del caso en que éste se proyecta en el tiempo, ofrece un contenido distintivo particular relevante a tener en cuenta $^{109}$. Primero pues aporta una explicación concreta a las diferencias penológicas que el legislador propone para las hipótesis que considera punibles bajo el título de las amenazas coercitivas (condicionales) y su contraste con la sanción prevista para la coacción violenta ${ }^{110}$, a partir de que resulta posible en dicho caso identificar un contenido lesivo adicional (concretamente, una doble lesión) respecto al que aporta el carácter coercitivo de ambas modalidades. Así se explica que la amenaza condicional sea un atentado más gravoso en relación a los casos de violencia coercitiva inmediata y de "intimidación" (circunscritos a la advertencia de males inminentes) ${ }^{111}$. De paso, esta misma asunción ofrece una razón específica que explica por qué el legislador adopta la decisión de anticipar el momento de la

${ }^{107}$ En este mismo sentido ETCHEBERRY, Derecho Penal, cit. nota n ${ }^{\circ} 12$, T.IV, pp. 319 y 320 . En nuestro medio nacional OLIVER CALDERÓN, "Consideraciones", cit. nota $\mathrm{n}^{\circ} 18$, pp. 470 a 472, ofrece una conceptualización diversa, bajo el entendido de que la amenaza es una forma de expresión y la intimidación un resultado (asociado a un estado de conmoción psicológica asimilable al miedo), pudiendo concurrir, indistintamente, cualquier de ellas con independencia de la otra. En el mismo sentido, RODRIGUEZ DEVESA, José María, Derecho Penal español. Parte especial, 9a ed, Madrid: Edit. Artes Gráficas Carasa, 1983, p. 269.

${ }^{108}$ Conviene aclarar que el carácter inminente del contexto al que es referida la irrogación de un mal no depende de que este último se haya materializado o ejecutado a efectos de dar forma a la coerción, sino que incluye también su mera advertencia, con tal que el evento de su eventual concreción se ubique en el mismo contexto en el que es proferida. Es decir, no se trata de un carácter que dependa de la efectiva irrogación de un mal llevado a cabo con el objeto de constreñir la voluntad de otro por miedo, temor o simplemente por la decisión de evitar su continuación. Lo que se discute en relación a estos casos ("vis compulsiva") es si pueden ser calificados como una coerción violenta o como amenazas coercitivas que es algo distinto. Bascuñán (BASCUÑÁN RODRÍGUEZ, "La regulación”, cit. nota n², p. 301) la califica como una “amenaza” en base a la "funcionalidad coercitiva" que presenta en dichos casos el uso de la violencia pues la concreción actual del mal solo tiene sentido para incidir en la motivación de la víctima. En este mismo sentido, MIRA BENAVENT, "El concepto", cit. nota n $n^{\circ}$ 10, p. 157 a 159; MIR PUIG, "El delito", cit. nota n 15 , p. 279, y, a partir de la conceptualización de la amenaza como "delito de expresión”, GUZMÁN DÁLBORA, El delito, cit. nota n², pp. 228 y 229. Se debe tener en cuenta que de aceptarse la diferencia entre amenaza e intimidación a partir del criterio que ofrece la inminencia de la irrogación del mal, la funcionalidad que advierten en estos autores llevaría a incluirla en esta última categorización, manteniendo su carácter "no violento". Volveremos sobre ello en al finalizar estas líneas.

${ }^{109}$ En el mismo sentido, si bien no a los mismos efectos, JASO ROLDÁN, "Capítulo XXX”, cit. nota n¹7, pp. 302 y 303. Implícito, ETCHEBERRY, Derecho Penal, cit. nota nº 12, T.IV, pp. 319 y 320.

${ }^{110}$ En España se le atribuye a Jaso Roldán un carácter fundacional en torno a esta tesis. En este sentido, BASCUÑÁN RODRÍGUEZ, "El Robo", cit. nota n4, p. 195, LARRAURI, Libertad, cit. nota n 17, p. 225. Se suelen radicar sus orígenes en general en Carrara (en este sentido, por todos, MIRA BENAVENT, "El concepto", cit. nota n ${ }^{\circ} 10$, p. 155) y, parcialmente, en España en Groizard (LARRAURI, Libertad, cit. nota $n^{\circ}$ 17 , p. 248 a 251)

${ }^{111}$ Se trata en el fondo de una solución concursal ad-hoc, que combina el sentido del acto de coerción con el que tiene asignada la amenaza. De hecho, la posibilidad de valorar paralelamente el medio comisivo cuando el legislador le atribuye relevancia penal autónoma o independiente es reconocida implícitamente por Bascuñán (p.297 y 301), toda vez que admite que en aquellos casos en que la amenaza condicional se lleva a cabo mediante violencia actual (bajo la advertencia de su continuación si se no satisface la condición) esta última debe ser valorada acorde a su mérito incriminatorio propio, configurando en su caso una hipótesis concursal. 
MALDONADO, Francisco. "Amenazas y coacciones en el Derecho Penal Chileno”.

consumación en las amenazas coercitivas (condicionales) teniendo en cuenta que el solo hito que representa su expresión ofrece un contenido que es calificado como autónomamente relevante a efectos de su punición. De esta forma, la ejecución "perfecta" del correspondiente contenido de injusto se corresponde con la hipótesis de amenaza coercitiva de condición cumplida $^{112}$, debiendo identificarse el caso inverso (cuando la condición no se cumple) como un delito de mera actividad y de resultado cortado ${ }^{113}$ que, a nivel material, corresponde a la "tentativa acabada" de dicha ejecución ("perfecta").

La tesis propuesta es tratada en la actualidad como una aproximación "histórica" o superada ${ }^{114}$. No obstante, los pocos argumentos formulados en contra no resultan concluyentes. A nivel material se sostiene que el carácter futuro del mal es irrelevante para configurar un atentado a las condiciones de seguridad del individuo o -en términos inversos pero equivalentes- que no resulta posible diferenciar realmente la amenaza de la intimidación asumiendo que en todos los casos de amenaza el mal que se utiliza para conminar a la víctima se expresa en condiciones de futuro ${ }^{115}$. Se sostiene por ello que el criterio propuesto resulta inútil o, cuando menos, débil o "poco nítido" para ofrecer una delimitación objetiva que habilite a extraer conclusiones como las señaladas ${ }^{116}$. Sin embargo, dichas observaciones parecen no advertir que el problema que supone la valoración del significado que tiene la advertencia de ejecución de un mal en casos de inminencia no pasa por su desconocimiento sino por un razonamiento diverso, referido a la (im)posibilidad de atribuirle relevancia en forma autónoma o independiente: la inminencia hace que dicho hito se vincule necesaria y estrechamente al desvalor que cabe asignar a su concreción (ejecución de la lesión) o, en su caso, a la constatación de su ausencia (y por ende de su insignificancia). Lo que sucede por ello es que su contenido "de futuro" se consume o absorbe por aquél que cabe asignar al correspondiente desenlace, cualquiera sea el escenario final (lesivo o inofensivo) ${ }^{117}$. La

${ }^{112} \mathrm{Al}$ respecto véase, TORÍO LÓPEZ, "La estructura", cit. nota $\mathrm{n}^{\circ}$ 12, p. 22. En este mismo sentido (si bien con una terminología diversa, pero equivalente) JAREÑO LEAL, Las amenazas, cit. nota nº 17, pp. 34 y ss. En contra Bascuñán, pp. 289 y ss.

${ }^{113}$ Lo justifica con razones equivalentes -si bien no idénticas- BASCUÑÁN RODRÍGUEZ, "La regulación", cit. nota ${ }^{\circ 2}$, pp. 291 y 292. Hay que tener en cuenta que Bascuñán no aporta más datos para explicar la consideración de una estructura típica diversa para esta modalidad. Destaca asimismo las ventajas interpretativas en pp. 292 y 293.

${ }^{114}$ BASCUÑÁN RODRÍGUEZ, "La regulación”, cit. nota n², p. 296. ETCHEBERRY, Derecho Penal, cit. nota $\mathrm{n}^{\circ} 12$, T. III, p. 246, menciona esta variante como una doctrina que sostenida "en su tiempo" en el derecho español. En el derecho español, véase la sintética exposición sobre el curso de esta forma de comprensión en LORENZO SALGADO, "El delito", cit. nota n 17, pp. 274 y ss. Con mayor detalle en LARRAURI, Libertad, cit. nota $\mathrm{n}^{\circ} 17$, pp. 244 y ss. Esta última autora destaca asimismo su relevancia histórica, en doctrina y jurisprudencia, LARRAURI, Libertad, cit. nota ${ }^{\circ}$ 17, en p. 248.

${ }_{115}$ MIR PUIG, "El delito", cit. nota no 15, p. 283. MIRA BENAVENT, "El concepto", cit. nota n ${ }^{\circ} 10$, pp. 155 y 156; RODRIGUEZ DEVESA, Derecho Penal, cit. nota $n^{\circ} 107$, p. 270. Ambos efectos son en todo caso extraídos en este autor de la necesidad de que la advertencia del mal sea idónea para "infundir temor" en el destinatario.

${ }^{116}$ La observación se atribuye en sentido original a MIR PUIG, "El delito", cit. nota no 15, p. 283. Adhieren LORENZO SALGADO, "El delito", cit. nota no 17, p. 275; MIRA BENAVENT, "El concepto", cit. nota n 10, p. 156; LARRAURI, Libertad, cit. nota n $^{\circ} 17$, p. 257

${ }^{117}$ Hemos ya anticipado que en términos técnicos opera una consunción (ordinaria o en su caso "inversa") donde el desvalor o irrelevancia penal del acto concretiza el significado que cabe asignar a la advertencia previa. En cualquier caso, debemos hacer constar que las hipótesis en las que no se produce el efecto coercitivo podrían perfectamente ser adscritas en torno alguna fase del iter criminis, habilitando a que se llegue a sancionar el 
Polít. crim. Vol. 13, № 25 (Julio 2018) Art. 1, pp. 1-41.

[http://www.politicacriminal.cl/Vol_13/n_25/Vol13N25A1.pdf]

desconexión que puede llegar a ofrecer la falta de dicha unidad de contexto impide dicha operación, haciendo posible reconocer la eventualidad e incertidumbre del mal más allá de dicho hito. Dicha "vigencia" neutraliza la insignificancia valorativa que cabe asignarle cuando pertenece al mismo contexto en que es proferida ${ }^{118}$.

En otro plano -más pragmático- se argumenta que la diferenciación propuesta es irrelevante como criterio distintivo, pues en cualquier caso se podrá advertir una afectación equivalente en la autodeterminación de la víctima ${ }^{119}$. Dicha asunción no solo desconoce que la conminación inminente presenta un mayor desvalor como acto coercitivo, por el hecho de que en dicho contexto el radio de actuación del destinatario -sus posibilidades de recurrir a otras alternativas para evitar la constricción- se ve de facto más reducido ${ }^{120}$. Además - y esto es lo realmente importante a los efectos que ahora nos ocupan- se trata de una observación que no tiene en cuenta que el plus de lesividad que se propone reconocer para la amenaza condicional se basa en la advertencia de una lesión adicional y distinta, referida a la seguridad y no a la libertad individual. Por ello resulta del todo irrelevante lo que se pueda postular en relación a la afectación de la libertad ${ }^{121}$.

Esta misma razón permite también descartar otras observaciones similares, a pesar de que parecieran ofrecer una mayor plausibilidad. Bascuñán, por ejemplo, sostiene que esta tesis resulta incompatible con la pretensión de asimilar el tratamiento asignado a todas las formas comisivas de la coerción ${ }^{122}$, sin tener en cuenta que dicha asimilación se basa en la exclusiva conceptualización de ambos casos como hipótesis de coerción (como actos que afectan a la libertad de autodeterminación) sin que por ello aporte algo en lo referido a la eventual

riesgo de afectación de la libertad pues todo lo dicho en el texto solo aplica, concretamente, a la eventual afectación de la seguridad. El que no se haga en el texto positivo probablemente se explica por el escaso desvalor que el legislador asigna a la coerción y que se refleja en el criterio general que se adopta a este respecto en relación a todas las faltas, en el sentido de penalizarlas sólo si se encuentran consumadas.

118 Esto mismo explica por qué no parece necesario que el carácter futuro del mal aparezca expresamente exigido en la ley (en este sentido LARRAURI, Libertad, cit. nota $\mathrm{n}^{\circ} 17$, p. 257) en tanto se trata de un resultado propio de la forma como se desarrollan los hechos en cada grupo de casos. Asimismo, da cuenta de un conjunto de efectos concretos que llevan a descartar la idea de que las diferencias radiquen solo en el fin del autor, o en la forma que éste escoja -libremente- para llevar a cabo la coerción. En el sentido objetado, LARRAURI, Libertad, cit. nota $\mathrm{n}^{\mathrm{o}} 17$, p. 258.

${ }^{119}$ LARRAURI, Libertad, cit. nota no 17 , pp. 121 y 122.

${ }^{120}$ En este sentido MIRA BENAVENT, "El concepto", cit. nota no 10, p. 155; BASCUÑÁN RODRÍGUEZ, “La regulación”, cit. nota $\mathrm{n}^{\circ} 2$, p. 296. “(...) la distinción entre la proximidad o futuridad de la irrogación del mal conminado sí es político-criminalmente relevante. Pues una amenaza de mal de próxima irrogación coloca al amenazado en la situación de tener que resolver de inmediato si accede a las exigencias o padece la amenaza, sin permitirle ninguna de las alternativas de defensa que posibilita una amenaza de mal de futura irrogación, entre las cuales se cuenta solicitar protección del Estado". Conviene tener en cuenta que en tiempos más antiguos se llegó a sostener precisamente lo contrario sobre razones poco atendibles. Para una acertada crítica LARRAURI, Libertad, cit. nota $\mathrm{n}^{\circ} 17$, pp. 249 y 250.

${ }^{121}$ Por esta misma razón también resulta incorrecto sostener una crítica a partir de la constatación de que la "futureidad del mal" nada aporta a efectos distintivos en cuanto a la idoneidad de la correspondiente advertencia para incidir en la libertad del destinatario (en este sentido MIRA BENAVENT, "El concepto", cit. nota n 10, pp. 155 y 156), pues el que dicha asunción sea correcta nada dice sobre la afectación de la seguridad individual, que es la razón que lleva a asignar importancia a la distinción.

${ }^{122}$ Concretamente como crítica a la propuesta de Jaso Roldán (equivalente a la sostenida en el texto). Al respecto BASCUÑÁN RODRÍGUEZ, “La regulación”, cit. nota n², pp. 192 y 193. 


\section{MALDONADO, Francisco. “Amenazas y coacciones en el Derecho Penal Chileno”.}

concurrencia de un significado alternativo y adicional que sea relevante valorar ${ }^{123}$. En este mismo sentido se reitera también acá -en términos críticos- la tradicional referencia a que la amenaza sanciona un riesgo y la coacción una lesión (del mismo bien jurídico) ${ }^{124}$, en un argumento que también se estructura al margen del desvalor asociado a la afectación de la seguridad. De esta forma, se trata de una objeción que tampoco aporta a los efectos de rechazar la idea de que es ésta la razón que explica que la amenaza condicional tenga asignada una mayor pena que la coacción ${ }^{125}$.

Finalmente, conviene poner de relieve que la plausibilidad de la tesis no solo se confirma en el hecho de que es la única fórmula propuesta que resulta compatible con las valoraciones penológicas que expone el legislador. También se advierte tras otras definiciones de derecho positivo. Así, por ejemplo, hay que tener en cuenta que la "amenaza" (seria y verosímil) de ejecución de un mal "exigiendo una cantidad" se califica expresamente como una hipótesis de amenaza condicional ${ }^{126}$, evidenciando un supuesto que en sus elementos constitutivos

${ }^{123}$ De fondo compartimos plenamente la orientación y razones de la asimilación. Ello supone sin embargo suprimir la relevancia que en la actualidad detenta la protección de la seguridad a través de la hipótesis de amenaza simple, en tanto solo de esa forma se puede proceder a obviar el desvalor que ello propone también en estos casos. En su caso, también está la opción de que se ofrezca una regulación más equilibrada o proporcional acorde a la entidad y gravedad que ofrece comparativamente la afectación de la seguridad individual y la libertad de autodeterminación. De esta forma, si la amenaza simple tuviese asignada una pena menor a la prevista para los casos de coerción su incidencia podría llegar a ser considerada irrelevante, habilitando a que se regulen las diversas hipótesis en términos plenamente equivalentes. Cuando menos, en las definiciones propias de la determinación legal de la pena (y, en especial, del respectivo marco penal).

${ }^{124}$ LORENZO SALGADO, "El delito", cit. nota n 17, pp. 275 a 277; En este sentido, LARRAURI, Libertad, cit. nota $\mathrm{n}^{\circ} 17$, p. 259; MIRA BENAVENT, "El concepto", cit. nota ${ }^{\circ} 10$ p. 155.

${ }^{125}$ A este respecto conviene hacer presente un matiz que en general suele pasar inadvertido. El análisis comparativo, a efectos de una eventual desproporción, se debe realizar entre los supuestos equivalentes, esto es, entre la amenaza coercitiva de condición cumplida y la coacción efectiva. Puestos -esos casos- en la balanza se puede advertir la real dimensión o gravedad de la desproporción que ello sugiere, al menos en lo que respecta al tratamiento que debiesen tener como actos coercitivos (y, desde esa perspectiva, equivalentes). En este sentido, se puede sostener que resulta particularmente exagerado el efecto que el legislador asigna a la afectación de la seguridad individual, más aun teniendo en cuenta que la mayor gravedad que cabe predicar de los supuestos de inminencia favorecería la idea de un tratamiento más atenuado en la sanción de la amenaza condicional, al menos en su valoración como acto coercitivo (para dar cuenta del menor desvalor comparativo que detenta respecto a los casos de coerción pura o intimidación). En este sentido BASCUÑÁN RODRÍGUEZ, "La regulación", cit. nota n², pp. 294 a 296 y 301; MIRA BENAVENT, "El concepto", cit. nota n 10, pp. 157 a 159. Sobre esa base, la distancia que existe en la gravedad que el legislador asigna a ambas sanciones no parece razonable, aun y cuando se tuviese en cuenta el mayor desvalor de la coerción inminente -en cuanto acto coercitivo- y el que cabe asignar al atentado a la seguridad individual en la amenaza condicional. Probablemente ello se debe al tratamiento particularmente gravoso que el derecho chileno concede a la regulación de las amenazas (condicionales y no condicionales) y que representa un aspecto distintivo de nuestra regulación local. Al respecto véase BASCUÑ̃́N RODRÍGUEZ, "El Robo", cit. nota nº 4, p. 101. En este contexto, se debe tener en cuenta que la anticipación que supone la sanción de la amenaza coercitiva no cumplida es algo secundario o contingente, pues dicha hipótesis debe ser considerada -y tratada- como un caso de ejecución incompleta (sancionada autónomamente por un motivo diverso ya explicitado). Con ello el que se asigne más pena "al riesgo que a la lesión" del mismo bien jurídico es una frase equívoca pues no es más que una consecuencia de la desproporción que se constata en los supuestos de ejecución acabada (consumada). Finalmente, sobre un criterio diverso al propuesto a efectos del análisis comparativo véase BASCUÑÁN RODRÍGUEZ, "El Robo", cit. nota $\mathrm{n}^{\circ} 4$, pp. 101 y 102.

${ }^{126}$ Art. 296 nº 1 del Código Penal. 
Polít. crim. Vol. 13, № 25 (Julio 2018) Art. 1, pp. 1-41.

\section{[http://www.politicacriminal.cl/Vol_13/n_25/Vol13N25A1.pdf]}

resulta plenamente equivalente a la ejecución de un delito de robo con "intimidación"127. La única forma de evitar el "concurso aparente" (difícil de resolver ${ }^{128}$ ) la propone precisamente la diferencia que postulamos entre la amenaza y la intimidación, a partir de la inminencia que caracteriza a la eventual ejecución del mal en esta última ${ }^{129}$. Con ello, quien advierte a un tercero "te mataré si no me entregas un millón de pesos" comete robo solo si la entrega y el daño son previstos en dicha advertencia como eventualidades pertenecientes al mismo contexto, incurriendo en un delito de amenazas condicionales en caso contrario.

Ahora bien, nada de lo dicho hasta el momento habilita a sostener que el tratamiento de la coerción mediante amenaza inminente ("intimidación") se encuentre reconocida en Chile como forma comisiva punible, pues ello supone admitir que dicha modalidad satisface el carácter "violento" que se exige en la configuración de una coacción ${ }^{130}$. Los argumentos expuestos se limitan a favorecer la tesis de que no se trata de hipótesis que puedan subsumirse en las amenazas condicionales y se basan en razones que poco tienen que ver con la eventual calificación del modo comisivo que adopta la coacción, en particular, con la posibilidad de calificarlo como "violento"131. Ello depende del grado de "espiritualización" que pueda tolerarse respecto a la interpretación de dicha calificación siendo en general dominantes las opiniones que favorecen la idea de que se debe relajar -y, en ese sentido, “espiritualizar"- el concepto de violencia, según ya hemos advertido ${ }^{132}$. Frente al dilema propuesto las opciones conclusivas solo pueden ser dos: la intimidación, cuando menos en ciertos casos, puede y debe ser considerada como una hipótesis de violencia a los efectos de la falta de coacciones, o se debe concluir sin más que el legislador ha optado por dejarla en la impunidad.

\footnotetext{
${ }^{127} \mathrm{Al}$ respecto véase el tratamiento de la intimidación en el delito de robo propuesta por OLIVER CALDERÓN, "Consideraciones", cit. nota $\mathrm{n}^{\circ} 18$, pp. 472 y 473. Si bien dicho autor concluye que no es necesario que la intimidación sea inminente (en referencia al mal que se advierte) si se requiere que "la entrega de la cosa" se produzca en el mismo contexto. Al respecto véanse también las citas nacionales que incluye al pie de página donde se puede consultar la opinión particular sobre este punto del resto de la doctrina local.

${ }^{128}$ Cabe destacar que el concurso aparente de leyes penales no puede ser resuelto en este caso por razones de especialidad, de consunción ni de subsidiariedad.

${ }_{129}$ El caso se propone en LARRAURI, Libertad, cit. nota $n^{\circ} 17$, p. 246. Se trata también en BUSTOS RAMÍREZ, Manual, cit. nota $n^{\circ} 39$, p. 98, quien destaca concretamente que la jurisprudencia española los resuelve -a su juicio erróneamente- en base al parámetro que sugiere el carácter futuro del mal.

${ }^{130}$ Esta asunción no parece haber sido comprendida por la doctrina española que en su momento favoreció esta tesis interpretativa. De hecho, se le atribuye como objetivo el dar razones que permitan entender que los casos de "intimidación" (advertencia de males conminatoria inminente) deben quedar comprendidos en el medio comisivo de las coacciones ("violencia"). En este sentido, LORENZO SALGADO, "El delito", cit. nota no 17, p. 274; BASCUÑÁN RODRÍGUEZ, "La regulación", cit. nota n², pp. 295 y 296. De ahí que sea correcta la crítica en cuanto a que el legislador distingue violencia e intimidación (sin incluir esta última como modo comisivo del tipo de coacciones en el derecho español), sin que de ello se extraiga argumento alguno en contra de la tesis propuesta: la inminencia permite diferenciar dichos casos de coerción de los que pueden ser conceptualizados como amenazas, pero no implica que puedan quedar comprendidos en la expresión "violencia". En el sentido objetado, LORENZO SALGADO, "El delito", cit. nota nº 17, p. 276.

${ }^{131}$ Se trata a fin de cuentas de distinciones diversas y por ello no excluyentes.

${ }^{132} \mathrm{Al}$ respecto véase la nota 61 precedente. El primer criterio constituye la opinión dominante en la doctrina alemana (véase, por todos, BASCUÑÁN RODRÍGUEZ, "La regulación", cit. nota n², p. 297). De ahí que RAGUÉS I VALLES, "Coacciones", cit. nota $\mathrm{n}^{\circ} 60$, p. 486 vincule la tendencia a espiritualizar la "violencia" con la corriente que tiende a acotar las amenazas a la advertencia de un mal futuro en la medida que permite identificar los casos de intimidación en torno al supuesto de la coacción sustrayéndolos del que es propio de la amenaza. En la doctrina española esta última es también la opción dominante.
} 


\section{MALDONADO, Francisco. “Amenazas y coacciones en el Derecho Penal Chileno”.}

Como punto de partida se debe tener en cuenta que la coerción (esto es, la afectación de la libertad de autodeterminación) se puede llevar a cabo a través de diversas formas comisivas o tipos de comportamiento. Nuestro legislador se inclina por un criterio de sistematización que diferencia estos modos o formas según si se desarrollan a través de medios violentos o no violentos, asimilándose -en general- estos últimos a formas de conducta constitutivas de "intimidación" (o amenaza, en los términos de la doctrina dominante) ${ }^{133}$. Dicho supuesto lleva a dos conclusiones relevantes de tener en cuenta: primero, el que no existen amenazas o formas de intimidación de carácter violento ${ }^{134}$; y segundo, que dicha calificación se

${ }^{133}$ Debemos advertir que a pesar de las apariencias se trata de una diferenciación oscura. Entendida en referencia a la materialidad del acto (según si se trata de una modalidad de interacción coercitiva que se desarrolla a través del despliegue de una intervención física sobre la actuación o voluntad de la víctima o si, por el contrario, se limita a la interacción comunicativa o "verbal" sobre su voluntad) termina por resultar inocua o irrelevante como factor de diferenciación. Si por el contrario se la asume como expresiva de una determinada forma de afectación de la libertad (sea en referencia al carácter absoluto o relativo de la "vis" o en relación al tipo de expresión de la libertad sobre el que incide -capacidad de decisión; motivación o capacidad de ejecución-) resulta poco clara como criterio de diferenciación. Sobre ambas conceptualizaciones véase en forma clara y sintética BASCUÑÁN RODRÍGUEZ, “\&6. Delitos”, cit. nota n 19, p. 3. Por sobre ello constituye además una opción poco precisa a los efectos de dar cuenta de todos los casos y diferencias relevantes de considerar pues existen formas o modos de coerción que no se identifican en forma propia con ninguno de estos conceptos. Además del engaño o "ardid" (BASCUÑÁN RODRÍGUEZ, "El Robo", cit. nota n4, p. 100; JAKOBS, "Coacciones", cit. nota $\mathrm{n}^{\circ} 13$, pp. 456 y ss.) puede haber formas no violentas ni intimidatorias directas que sirven a efectos coercitivos Así sucede con los casos asociados a la idea de "fuerza sobre las cosas" y a la generación de contextos indeseables y actos de hostigamiento. Al respecto BASCUÑÁN RODRÍGUEZ, "La regulación”, cit. nota n², pp. 298 y 299; MIR PUIG, "El delito", cit. nota n 15, pp. 275 y 276, con desarrollo jurisprudencial en pp. 281 a 283 y análisis posterior en pp. 286 y 287; se menciona también en MATUS ACUÑA y RAMÍREZ, Lecciones, cit. nota $\mathrm{n}^{\circ} 19$, p. 223. La virtual ausencia de tratamiento sistemático evidencia la necesidad de una mayor dedicación por parte de la doctrina y redunda en una diversidad de intentos tendientes a dar cabida a dichas formas dentro de los actos violentos o dentro de la intimidación, cuando menos a aquellos supuestos que parecieran ofrecer mérito para fundar una incriminación. Todo ello no ha hecho más que contribuir a una mayor incertidumbre o indeterminación en la precisión, contornos y límites de ambos conceptos. A este respecto se puede revisar una visión crítica sobre dicha "ampliación” (asociada al tratamiento de los casos catalogados como propios de la vis compulsiva no conminatoria) en BASCUÑ́́N RODRÍGUEZ, "La regulación", cit. nota $n^{\circ} 2$, p. 299. Véase al respecto el análisis del caso de "obstrucción de una vía" propuesto por HRUSCHKA, "La coacción”, cit. nota $\mathrm{n}^{\circ}$ 60, pp. 285 y ss. y, en especial, las razones para calificarlos como violencia. Igualmente, MIRA BENAVENT, "El concepto”, cit. nota no 10, pp. 165 y ss., detalla una serie de casos jurisprudenciales en que se aplica la coacción a hechos no violentos por el carácter conminatorio de las respectivas acciones. En similares términos, JAKOBS, "Coacciones", cit. nota n 13, pp. 449 y 450 . En Chile, contra su consideración como formas de violencia, SOTO PIÑEIRO, "Nota y comentario", cit. nota n ${ }^{\circ} 18$, pp. 123 y 126; en una posición intermedia OLIVER CALDERÓN, "Consideraciones", cit. nota $\mathrm{n}^{\circ} 18$, p. 467, quien sostiene que la mayoría de los casos pueden configurar “intimidación” y, por excepción, "violencia".

${ }^{134}$ Una opinión diversa se advierte en GUZMÁN DÁLBORA, El delito, cit. nota n², pp. 228 y 229, quien se basa en la configuración de las amenazas como delito "de expresión”. Por ello entiende que si el ejercicio de violencia activa realizada a efectos de generar un proceso de interacción sensitiva con la víctima debe siempre circunscribirse en el marco de las amenazas. Así, quien retiene y golpea a un individuo sorprendido in fraganti para que delate a sus cómplices por temor a que los golpes continúen materializa una coerción mediante amenaza, a pesar de que dichos golpes constituyen sin lugar a dudas una modalidad de conducta de carácter violento. La ausencia de dicho resultado o efecto - la funcionalidad de la violencia a efectos de materializar la constricción por medios físicos- habrá que dar lugar a la hipótesis de coacción. Agrega a ello que el delito de amenazas está concebido con medios libres o abiertos lo que supone que se puede ejecutar tanto mediante medios morales como a través de violencia o ejercicio de fuerza física, a diferencia de las coacciones. Por el 
Polít. crim. Vol. 13, № 25 (Julio 2018) Art. 1, pp. 1-41.

[http://www.politicacriminal.cl/Vol_13/n_25/Vol13N25A1.pdf]

determina por la materialidad del comportamiento, según si se trata de casos de fuerza "moral" -entendida como "verbal"- o fuerza "física". Siendo así, el hecho de que legislador limite la punibilidad de la coacción a aquellas que son violentas en exclusiva favorece la opción de entender que quiso dejar impune a la coerción "no violenta" de carácter inminente. De ahí que nos parezcan acertadas las observaciones que a este respecto sostiene Etcheberry, quien entiende que la tradicional equiparación que el legislador expresa entre la violencia y la intimidación encuentran en este caso una concreta e inexplicable excepción que lleva a excluir "toda advertencia de males" del contexto de la coacción por razones de texto expreso $^{135}$. Lo dicho se refuerza por el hecho de que efectivamente el legislador suele equiparar y tratar de forma equivalente o paralela a la violencia y a la intimidación, utilizando precisamente dicha denominación ${ }^{136}$, y por el hecho de que resultan indiscutibles a este respecto los límites que imponen las exigencias de certeza y precisión que se asocian al principio de legalidad ${ }^{137}$.

El que en este caso en particular -excepcionalmente- haya adoptado un criterio diverso al general requiere por ello una explicación, la que aparentemente solo encuentra sentido en atención a consideraciones históricas. Las opiniones al respecto suelen coincidir en las razones que incidieron en la decisión de acotar al mínimo la punibilidad prevista para los casos de coerción. Primero, pues nadie discute la escasa relevancia que se asignó a la protección general de la libertad de autodeterminación, lo que no solo decanta en la

contrario, la opinión de Bascuñán se corresponde con lo sostenido en el texto, a pesar de que a primera vista pareciera contradictorio. Bascuñán también califica los casos que etiqueta como "vis compulsiva conminatoria" como amenaza, lo que incluye todas las hipótesis en que el ejercicio actual de violencia física tiende a constreñir a la víctima por temor a su repetición. Mas ello se explica por cuanto en su concepto constituye una hipótesis de intimidación y no de violencia bajo el entendido de que la primera incluye todo tipo de "mince", incluyendo la "intimidación". Al respecto BASCUÑÁN RODRÍGUEZ, "La regulación”, cit. nota n², pp. 295 a 300.

${ }^{135}$ ETCHEBERRY, Derecho Penal, cit. nota no 12, T. III, pp. 246 y 247.

${ }^{136}$ Es un hecho que el legislador las suele equiparar, mencionar y tratar conjuntamente cuando requiere recurrir a la definición de medios coactivos. Constituyen por ello, en forma prototípica, las modalidades de la acción cuando se requiere una modalidad comisiva que tenga dicho carácter. De ahí que la decisión adoptada en este caso pareciera demandar un criterio o razón material particular. Al respecto BASCUÑÁN RODRÍGUEZ, "El Robo", cit. nota n4, p. 109. En este mismo sentido MIRA BENAVENT, "El concepto", cit. nota no 10, quien también destaca el uso habitual que el legislador hace de las expresiones "violencia o intimidación" (p. 157) y coincide en su tratamiento (de la intimidación) bajo el título de las amenazas (pp. 154 y 155). En el mismo sentido, MIR PUIG, "El delito", cit. nota $\mathrm{n}^{\circ} 15$, p. 284. Finalmente conviene advertir que el paralelismo que sugiere el legislador es utilizado en SOTO PIÑEIRO, "Nota y comentario", cit. nota no 18, p. 123 para concluir precisamente lo contrario, esto es, que la referencia a la "violencia" -sólo por razones que califica como sistemáticas- debe incluir a la intimidación, más allá de reconocer que se trata de una interpretación que contraría el sentido natural del término y que se muestra como excepcional (p. 124).

${ }^{137}$ Decididamente RAGUÉS I VALLES, "Coacciones", cit. nota $\mathrm{n}^{\circ}$ 60, p. 492 quien identifica la tendencia a espiritualizar la violencia con la discrepancia que la doctrina manifiesta con la decisión legislativa, a partir del objetivo de brindar una protección más amplia a la libertad de autodeterminación. En concreto, analiza (pp. 489 a 492) el planteamiento que Jakobs expone en ese sentido (pp. 458 y 459). Aporta además un elemento de juicio interesante pues destaca que el TC alemán puso freno en 1995 a la tendencia a espiritualizar la expresión "violencia" en base a argumentos equivalentes (p. 488). Lo trata igualmente BASCUÑÁN RODRÍGUEZ, "La protección", cit. nota $\mathrm{n}^{\circ} 2$, p. 19. HRUSCHKA, "La coacción", cit. nota $\mathrm{n}^{\circ} 60$, p. 258, ratifica esto último afirmando - como conclusión- que "el concepto "desmaterializado", "espiritualizado" de violencia ha llegado con esto a su final". Crítico también por consideraciones materiales TORÍO LÓPEZ, "La estructura", cit. nota $\mathrm{n}^{\circ} 12$, pp. 23 y 24. 
consagración de una figura de coerción de carácter genérico y muy básica, bajo el entendido de que los casos más importantes se encuentran consagrados en forma específica a través de diversas figuras y tipos penales particulares. Y, en segundo lugar, por cuanto el carácter genérico de la idea de autodeterminación provocó un profundo temor asociado a su potencial amplitud, en particular, a que por esta vía se llegue a penalizar una serie de casos del todo insignificantes ${ }^{138}$. Así se explica el que se haya recurrido a un criterio pragmático y de carácter material que se identifica históricamente en torno al sentido que aporta el tradicional crimen vis. Dicha noción -que se remonta a la regulación romana- sugiere la asignación de un determinado y particular (des)valor a todo acto que constituya un maltrato de carácter físico, en tanto se lo (des)valora como expresión de violencia privada que por ello afecta el monopolio del ejercicio de la fuerza por parte del Estado ${ }^{139}$.

Con ello, se plantea una cuestión adicional, pues se debe resolver si la violencia debe ser entendida -en oposición a la intimidación- a partir de una aproximación funcional o si por el contrario debe ser interpretada con una base material (como "maltrato" o "fuerza" de carácter "físico"). Lo relevante es que esta segunda alternativa admitiría como violencia los casos en que se intimida mediante la advertencia inminente de ejercicio de fuerza física y aquellos en que se usa fuerza física actual como medio coercitivo ${ }^{140}$. Por el contrario, conforme a la primera tesis la idea de "violencia" equivale a la afectación de la capacidad de adoptar decisiones o de obrar (ejecutarlas) mientras que la intimidación o amenaza se identifica con todas aquellas intervenciones que inciden sobre la capacidad de motivación del individuo acorde a fines propios ${ }^{141}$, de forma que ninguno de estos supuestos sería, bajo esta

138 JAKOBS, “Coacciones", cit. nota n' 13, p. 440.

139 Véase al respecto, por todos, MIR PUIG, "El delito", cit. nota $n^{\circ} 15$, p. 275. Una explicación de contexto histórico acerca del por qué las coacciones se limitaron al ejercicio de violencia en su tipificación se puede apreciar en LARRAURI, Libertad, cit. nota n 17, pp. 66 a 68. Asimismo, véase BASCUÑ́́N RODRÍGUEZ, "El Robo", cit. nota n4, p. 199, JAKOBS, “Coacciones”, cit. nota n 13, pp. 441 y 442; RAGUÉS I VALLES, "Coacciones", cit. nota $\mathrm{n}^{\circ}$ 60, p. 484; MIRA BENAVENT, Javier, cit. nota $\mathrm{n}^{\circ}$ 10, p. 100. Sobre la evolución posterior del tratamiento de la violencia, véase TORÍO LÓPEZ, "La estructura”, cit. nota no 12, pp. 24 y 25. HRUSCHKA, "La coacción”, cit. nota n 60, pp. 271 a 277 sugiere un origen diverso, al menos en la influencia de la regulación alemana de la coacción. Finalmente, según BASCUÑÁN RODRÍGUEZ, "El Robo", cit. nota $\mathrm{n}^{\circ} 4$, p. 2, la propia génesis de la coacción encuentra raíces en dicha expresión delictiva.

${ }^{140}$ En este sentido, RAGUÉS I VALLES, “Coacciones”, cit. nota no 60, p. 496, a partir de la compatibilidad del medio empleado con la comprensión "natural" de la expresión "violencia". En el mismo sentido MIR PUIG, "El delito", cit. nota $\mathrm{n}^{\circ} 15$, p. 277, si bien a partir de una concepción funcional de la violencia ("propia de su "normativización", según el mismo autor califica) más amplia, que por ello renuncia a la exigencia de fuerza física. MIR PUIG, "El delito", cit. nota n" 15, p. 280 sostiene asimismo que ello no contraría el "tenor literal posible" pues "obligar a otro es", a fin de cuentas, "violentarlo". No obstante, por razones penológicas (a fin de evitar un privilegio) las circunscribe en definitiva al ámbito típico de las amenazas (pp. 284 y 285). En contra BASCUÑÁN RODRÍGUEZ, “La regulación”, cit. nota n², p. 300 sostiene que el recurso a conceptos más bien "prácticos" como la fuerza física o moral, entre otros, no son funcionales al rol que le cabe al medio comisivo o al modo de ataque. De ahí, que, en su opinión, no lleguen a resultados satisfactorios.

${ }^{141}$ La utilidad de la tripartición clásica atribuida a Binding es evidente a dichos efectos en cuanto es precisamente la que permite identificar con nitidez las dos formas o modalidades de ejecución de la coerción. En particular se identifica a la amenaza con una interferencia en el proceso motivacional y la violencia con una interferencia la capacidad genérica de obrar (esto es, para la ejecución de decisiones o "capacidad de actuación"). Dicha asociación favorece la conceptualización del medio comisivo de las coacciones como equivalente a las vías de hecho, radicando todo tipo de advertencia de males en torno a las amenazas. Al respecto, sintético, LORENZO SALGADO, "El delito", cit. nota n 17, pp. 270 a 273; MIRA BENAVENT, 
Polít. crim. Vol. 13, № 25 (Julio 2018) Art. 1, pp. 1-41.

[http://www.politicacriminal.cl/Vol_13/n_25/Vol13N25A1.pdf]

comprensión, un acto constitutivo de violencia ${ }^{142}$. Al respecto, cabe tener en cuenta que solo los casos en que se usa fuerza física actual como medio coercitivo materializan una expresión coherente con el sentido histórico que es posible atribuir a la exigencia de violencia por parte del legislador, siendo a nuestro juicio los únicos que por ello admiten dicha calificación ${ }^{143}$.

\section{Consecuencias (conclusiones)}

1. De lege ferenda consideramos adecuado regular una hipótesis de coerción que incluya como modo comisivo la violencia y la amenaza, con independencia de su sentido de futuro. En su caso, parece también deseable la regulación de una hipótesis agravada en casos de inminencia. Todo ello supone tomar también la decisión de suprimir la relevancia penal de la amenaza simple o, cuando menos, acotarlo a un umbral de pena más bajo que el que se conceda a la coerción. Ello se justifica por su escaso desvalor, en tanto no constituye más que una excesiva anticipación punitiva que difícilmente da cuenta de un riesgo cierto o concreto de lesión. Sin perjuicio de esto, parece sensato que en aquellos casos donde sea posible atribuirle relevancia como en contextos de prevalimiento o en ámbitos de violencia intrafamiliar- se considere una particular regulación de dicho contenido, cuya concurrencia con la coerción debiese quedar entregada al tratamiento concursal general.

2. De lege lata:

a. La amenaza simple debe ser entendida e interpretada como forma de afectación de la seguridad individual referida a eventos que tienen relevancia penal; el dolo se orienta por ello a la consecución del mal; la seriedad y la verosimilitud se orientan a la constatación de un riesgo efectivo de ejecución futura del mal y a la percepción del mismo por parte del destinatario; y, en caso de ejecución del mal, debe operar la correspondiente regla de absorción (prevista en el art. 296 n³ del Código Penal).

\footnotetext{
“El concepto”, cit. nota no 10, pp. 128 y ss. BASCUÑÁN RODRÍGUEZ, "La regulación”, cit. nota n², pp. 293 y ss., y en, del mismo, La protección penal, pp. 18 a 23. Parece conveniente dejar constancia de que la doctrina tradicional pareciera haber confundido dicha función en forma histórica, bajo la errónea comprensión de que se trata de tres modalidades o formas que adoptaría la lesión de la libertad (esto es, como resultado). A este respecto se podrá advertir que si el resultado delictivo consiste en que el individuo deja de hacer algo que desea o hace algo que no quiere (por ejemplo, cumplir la condición) resulta irrelevante a dichos efectos que lo haga porque está inconsciente, tiene reducida su capacidad de decidir o está impedido de obrar, pues su libertad de autodeterminación aparece comprometida en todos esos casos en forma equivalente. Queda con ello en evidencia que se trata de una distinción que no da cuenta de resultados o consecuencias, sino de formas de intervención. Al respecto véase el tratamiento que expone Bascuñán (p. 282 a 288) con detalle.

${ }^{142}$ En este sentido BASCUÑÁN RODRÍGUEZ, "La regulación”, cit. nota n², pp. 293 y ss. y en BASCUÑÁN RODRÍGUEZ, "La protección”, cit. nota n², p. 17 y 23. MIR PUIG, "El delito", cit. nota no 15, p. 279. Así mismo MIRA BENAVENT, “El concepto”, cit. nota no 10, pp. 154 y 155.

${ }^{143}$ En este sentido TORÍO LÓPEZ, "La estructura”, cit. nota $n^{\circ} 12$, pp. 26 quien a pesar de sostener una conceptualización de carácter funcional concluye finalmente que la irrogación actual de un mal con fines conminatorios satisface las exigencias de un comportamiento violento. De esta forma, incluye como caso de intimidación o amenaza solo aquél en que aún no se ha irrogado mal físico, con tal que se haya advertido.
} 
MALDONADO, Francisco. “Amenazas y coacciones en el Derecho Penal Chileno”.

b. Por su parte, la amenaza condicional debe ser concebida como una forma de coerción. El dolo se orienta por ello a la realización de la condición; la seriedad y la verosimilitud se orientan a la constatación de un riesgo de afectación de la capacidad de decisión y motivación del individuo; el caso de ejecución del mal debe dar lugar a una hipótesis concursal (si constituye delito); es razonable que su sanción sea prevista en el derecho positivo con independencia del carácter delictivo del mal y en casos en que la imposición de un mal lícito es formulada en forma reprobable; su mayor gravedad, como hipótesis de coerción, solo se justifica si se trata de casos en que la advertencia del mal se emite con carácter futuro sin que sean típicos -bajo este título- los casos de inminencia (intimidación); esto mismo explica su configuración como delito de resultado cortado, si la condición no se ha cumplido y como figura perfecta (consumada) en caso contrario.

c. La coacción solo admite punición en casos de violencia física inminente. La intimidación, esto es, la advertencia de males inminentes, es impune bajo dicho título de incriminación. Los casos en que se ejecute un acto de fuerza física a efectos conminatorios son casos de violencia y, por ello, punibles bajo este título. No sucede lo mismo cuando la acción se limita a advertir su ejecución inminente.

d. Amenaza condicional y coacción se ubican en términos paralelos, abarcando cada uno de ellos, casos completamente diversos. Desde este punto de vista, constituyen (ambos) tipos de recibo de la parte especial en relación a todos los delitos cuya ejecución considera una forma de coerción punible. 
Polít. crim. Vol. 13, No 25 (Julio 2018) Art. 1, pp. 1-41.

[http://www.politicacriminal.cl/Vol_13/n_25/Vol13N25A1.pdf]

\section{Bibliografía}

BASCUÑÁN RODRÍGUEZ, Antonio, “\&6. Delitos contra la libertad”, material inédito asociado a la preparación de un manual destinado al tratamiento de la parte especial del Derecho penal facilitado por el autor.

BASCUÑÁN RODRÍGUEZ, Antonio, “Delitos contra intereses personalísimos”, en Revista de Derecho de la Universidad Adolfo Ibañez (2005), pp. 531 a 556.

BASCUÑÁN RODRÍGUEZ, Antonio, "La protección penal de la libertad personal”, material de estudio para los estudiantes de la Facultad de Derecho de la Universidad Adolfo Ibañez, 2001 - 2003, material inédito, facilitado por el autor.

BASCUÑÁN RODRÍGUEZ, Antonio, "El Robo como coacción”, en Revista de Estudios de la Justicia, $\mathrm{n}^{\circ} 1$ (2002), pp. 55 a 125.

BASCUÑÁN RODRÍGUEZ, Antonio, "La regulación española de la coerción en el marco de la codificación penal europea", en Anuario de Derecho Penal y Ciencias Penales, Tomo 47, Fasc. 3 (1994), pp. 191 a 306.

BUSTOS RAMÍREZ, Juan, Manual de Derecho Penal. Parte especial, $2^{\mathrm{a}}$ ed. Aumentada, corregida y puesta al día, Barcelona: Ariel Derecho, 1991.

CAMAÑO ROSA, Antonio, "Delitos contra la libertad", Anuario de Derecho Penal y Ciencias Penales, Tomo 20, Fasc. 1-2 (1967) pp. 59 a 96.

CARRARA, Francesco, Programa de Derecho Criminal, Parte especial, Volumen II, Bogotá (Colombia): Temis, 1986.

ETCHEBERRY, Alfredo, Derecho Penal, $3^{\circ}$ edición revisada y actualizada, Santiago (Chile): Editorial Jurídica de Chile, 1997.

FERNÁNDEZ, Pedro Javier, Código Penal de la República de Chile. Esplicado i concordado, $2^{\text {a }}$ edición, Tomo II, Santiago: Ediciones Imprenta, Litografía y Encuadernación, 1900.

FERNÁNDEZ DIAZ, Alvaro, “Amenaza de difundir información íntima: El caso que afectó al Conservador de Bienes Raíces de Santiago", en Revista Chilena de Derecho, vol. 35 nº1 (2008), pp. 183 a 191.

FUENZALIDA, Alejandro, Concordancias y comentarios del Código Penal Chileno, Santiago: Imprenta Comercial, 1883.

GUZMÁN DÁLBORA, José Luis, El delito de amenazas, Santiago: Editorial Jurídica Conosur, 1999. 
MALDONADO, Francisco. “Amenazas y coacciones en el Derecho Penal Chileno”.

HRUSCHKA, Joachim, "La coacción en el sistema del derecho penal”, en, EL MISMO, "Imputación y Derecho Penal. Estudios sobre la teoría de la imputación" (edición a cargo de Pablo Sanchez-Ostiz), Navarra: Edit. Thomson-Aranzadi, 2005, pp. 257 a 288.

JAKOBS, Günther, "Coacciones por medio de violencia", traducción y estudio preliminar a cargo de PEÑARANDA, SUÁREZ y CANCIO, en: EL MISMO, "Estudios de Derecho Penal", Madrid: Edit. Civitas, 1997, pp. 439 a 459.

JAKOBS, Günther, "Las coacciones mediante amenazas como delito contra la libertad", traducción y estudio preliminar a cargo de PEÑARANDA, SUÁREZ y CANCIO, en: EL MISMO, "Estudios de Derecho Penal", Madrid: Edit. Civitas, 1997, pp. 461 a 480.

JAREÑO LEAL, Angeles, Las amenazas y el chantaje en el Código Penal de 1995, Valencia: Tirant lo Blanch, 1997.

JASO ROLDÁN, Tomás, “Capítulo XXX”, en: ONECA, Antón y RODRÍGUEZ MUÑOZ, J.A., Derecho Penal. Tomo II. Parte especial, Madrid: Gráfica Administrativa, 1949.

LABATUT GLENA, Gustavo, Derecho Penal, Tomo II, $7^{\text {a }}$ edición actualizada por el profesor Julio Zenteno V., Santiago: Edit. Jurídica de Chile, 1996.

LARRAURI, Elena, Libertad y amenazas, Barcelona: Edit, PPU, 1987.

LORENZO SALGADO, José Manuel, "El delito de amenazas. Consideraciones sobre el bien jurídico protegido", en Estudios Penales y Criminológicos n¹2 (1987-1988), pp. 249 a 304 .

MAÑALICH R., Juan Pablo, Autotutela del acreedor y protección penal del deudor. La realización arbitraria del propio derecho frente a los delitos contra la libertad, la propiedad y el patrimonio, Santiago: Ediciones Jurídicas de Santiago, 2009.

MATUS ACUÑA, Jean Pierre, "La protección penal de la seguridad personal en el Código Penal", en Ius et Praxis, año 15, n¹ (2009), pp. 387 a 396.

MATUS ACUÑA, Jean Pierre y RAMÍREZ G., Cecilia, Lecciones de Derecho Penal Chileno. Parte Especial, Tomo I, Santiago: Edit. Thomson Reuters, 2015.

MERA FIGUEROA, Jorge, Hurto y Robo, Santiago: Edit. Lexis Nexis, 1995.

MIR PUIG, Santiago, "El delito de coacciones en el Código penal”, en Anuario de Derecho Penal y Ciencias Penales, Tomo XXX, Fasc. 2 (1977) pp. 269 a 306.

MIRA BENAVENT, Javier, "El concepto de violencia en el delito de coacciones", en Cuadernos de Política Criminal, No22 (1984), pp. 95 a 181. 
Polít. crim. Vol. 13, No 25 (Julio 2018) Art. 1, pp. 1-41.

[http://www.politicacriminal.cl/Vol_13/n_25/Vol13N25A1.pdf]

NOVOA MONREAL, Eduardo, "Cuestiones jurídicas relativas al delito de amenazas", en Revista de Ciencias Penales, segunda época, Tomo XII, no 1 y 2, Enero - Junio (1950), pp. 15 a 23.

OLIVER CALDERÓN, Guillermo, "Consideraciones sobre la violencia y la intimidación en el Robo", en VVAA, "La ciencia penal en la Universidad de Chile. Libro homenaje a los profesores del departamento de Ciencias Penales de la Facultad de Derecho de la Universidad de Chile", Santiago: Ediciones Universidad de Chile, 2013, pp. 463 a 479.

PAREDES CASTAÑÓN, José Manuel, "La seguridad como objetivo político criminal del sistema penal", en Eguzkilore n²0 (2016), pp. 129 a 149.

PAREDES CASTAÑÓN, José Manuel, "Libertad, seguridad y delitos de amenazas", en Estudios Penales y Criminológicos, Vol. XXIX (2009), pp. 363 a 419.

RAGUÉS I VALLES, Ramón, “Coacciones sin violencia. Apuntes sobre el difícil encaje de la legalidad en un sistema funcional del derecho penal", en MONTEALEGRE LYNETT, Eduardo (Coord.) Libro Homenaje al profesor Gunther Jakobs. El Funcionalismo en Derecho Penal, Bogotá (Colombia): Ediciones Universidad Externado de Colombia, Tomo II, 2003, p. 481 a 496.

RODRIGUEZ DEVESA, José María, Derecho Penal español. Parte especial, $9^{\mathrm{a}}$ ed, Madrid: Edit. Artes Gráficas Carasa, 1983.

SOTO PIÑEIRO, Miguel, "Nota y comentario de jurisprudencia 'Contra Jorge Cosmelli Misle"”, en Revista de Ciencias Penales NXXXIX, No2 (1987-1989), pp. 90 a 131.

TORÍO LÓPEZ, Angel, "La estructura típica del delito de coacción”, en Anuario de Derecho Penal y Ciencias Penales, Tomo XXX, Fasc. 1 (1977), pp. 19 a 40.

VERA, Robustiano, El Código Penal de la República de Chile comentado, Santiago: Imprenta de la P. Cador y cía, 1883. 